University of Montana

ScholarWorks at University of Montana

Numerical Terradynamic Simulation Group

Publications

Numerical Terradynamic Simulation Group

$7-2010$

\title{
Simulations show decreasing carbon stocks and potential for carbon emissions in Rocky Mountain forests over the next century
}

Céline Boisvenue

The University of Montana

Steven W. Running

University of Montana - Missoula

Follow this and additional works at: https://scholarworks.umt.edu/ntsg_pubs

Let us know how access to this document benefits you.

\section{Recommended Citation}

Boisvenue, C. and Running, S. W. (2010), Simulations show decreasing carbon stocks and potential for carbon emissions in Rocky Mountain forests over the next century. Ecological Applications, 20: 1302-1319. doi:10.1890/09-0504.1

This Article is brought to you for free and open access by the Numerical Terradynamic Simulation Group at ScholarWorks at University of Montana. It has been accepted for inclusion in Numerical Terradynamic Simulation Group Publications by an authorized administrator of ScholarWorks at University of Montana. For more information, please contact scholarworks@mso.umt.edu. 


\title{
Simulations show decreasing carbon stocks and potential for carbon emissions in Rocky Mountain forests over the next century
}

\author{
Céline Boisvenue ${ }^{1}$ and Steven W. Running
}

\author{
Numerical Terradynamic Simulation Group, University of Montana, Missoula, Montana 59802 USA
}

\begin{abstract}
Climate change has altered the environment in which forests grow, and climate change models predict more severe alterations to come. Forests have already responded to these changes, and the future temperature and precipitation scenarios are of foremost concern, especially in the mountainous western United States, where forests occur in the dry environments that interface with grasslands. The objective of this study was to understand the trade-offs between temperature and water controls on these forested sites in the context of available climate projections. Three temperature and precipitation scenarios from IPCC AR4 AOGCMs ranging in precipitation levels were input to the process model Biome-BGC for key forested sites in the northern U.S. Rocky Mountains. Despite the omission of natural and human-caused disturbances in our simulations, our results show consequential effects from these conservative future temperature and precipitation scenarios. According to these projections, if future precipitation and temperatures are similar to or drier than the dry scenario depicted here, high-elevation forests on both the drier and wetter sites, which have in the absence of disturbance accumulated carbon, will reduce their carbon accumulation. Under the marginally drier climate projections, most forests became carbon sources by the end of the simulation horizon (2089). Under all three scenarios, growing season lengthened, the number of days with snow on the ground decreased, peak snow occurred earlier, and water stress increased through the projection horizon (1950-2089) for all sites, which represent the temperature and precipitation spectrum of forests in this region. The quantity, form, and timing of precipitation ultimately drive the carbon accumulation trajectory of forests in this region.

Key words: carbon; climate change; forest; northern U.S. Rocky Mountains; water temperature balance.
\end{abstract}

\section{INTRODUCTION}

Documented climatic changes in the last 50 years have significantly changed the environmental conditions in which forests grow (Jones and Mann 2004). There is evidence that forests have already responded to these reported climatic changes (Boisvenue and Running 2006), and climatic changes are predicted to intensify in the coming decades (IPCC 2007). The recent Intergovernmental Panel for Climate Change (IPCC) Fourth Assessment Report (AR4) synthesizes much of the latest research on climate projection. The report predicts increases in temperatures and in the amount of precipitation at middle and high latitudes (IPCC 2007).

Forest vegetation requires sunlight, carbon dioxide, water, and a certain range in temperatures as a basis for photosynthesis. Carbon dioxide levels are not limiting in forests, and it is therefore possible to represent the

Manuscript received 25 March 2009; revised 22 October 2009; accepted 26 October 2009. Corresponding Editor: D. R. Zak.

${ }^{1}$ Present address: Natural Resources Canada, Canadian Forest Service, Laurentian Forestry Centre, 1055 du PEPS, P.O. Box 10380, Stn. Sainte-Foy, Québec QC G1V 4C7 Canada. E-mail: cboisven@NRCan.gc.ca variability in vegetation productivity across the globe by mapping the availability of radiation (light), water (in the soil and in the atmosphere with vapor pressure deficit [VPD]), and with an overlay of temperature limitations (Churkina and Running 1998, Nemani et al. 2003, Running et al. 2004). While the bulk of the variability in productivity can be represented by these three abiotic controls, a smaller portion of the variation in productivity is determined by the amount of foliage, the light use efficiency of this foliage, ambient temperature during growing season, availability of soil nutrients, the adaptation of species to extreme temperatures, and the efficiencies of water and nutrient use (Hopkins and Hüner 2004).

Precipitation levels, which are predicted to change, play a crucial role in forest ecosystems, especially on drier sites. The amount of water on site often drives productivity and disturbance regimes in dry-site forests. Fig. 1 illustrates the sequential constraints of light, VPD, and temperature on the growing-season physiological activity of a forested site in Missoula, Montana (Jolly et al. 2005). For this site, day length is the primary constraint from November to February; low temperatures constrain activity in late winter, spring, and fall; and water stress limits productivity in the warm months 
of summer. During the bulk of the growing season on this site, when light and low temperatures are not limiting, water drives the system. In Missoula, Montana, overall productivity depends on moisture conditions during the main part of the growing season. In turn, spring, summer, and autumn temperatures, as well as summer precipitation levels, and the previous winter's snow pack, determine these conditions.

The individual and combined effects of temperature and precipitation reach beyond a two-dimensional threshold effect created by the range of temperatures and the amount of water necessary for photosynthesis. Water stress suppresses photosynthesis by reducing light-use efficiency, and if water-limiting conditions persist, stomata close, halting the photosynthesis process. When water is not limiting, annual photosynthesis in forests is controlled by atmospheric conditions via their influence on absorbed photosynthetically active radiation (PAR) and the effects of available light and temperature on stomatal conductance (Waring and Running 2007). An increase in temperature may also increase vapor pressure deficit (VPD) of the air and thereby increase transpiration rates, resulting in adverse effects on drier sites, unless stomata close in response to other changes such as an increase in $\mathrm{CO}_{2}$, or if increases in nighttime temperature exceed increases during the day (Kirschbaum 2004). In addition, water and temperature also control decomposition and respiration levels in forest ecosystems; water can limit respiration by limiting growth and/or suppressing microbial respiration (e.g., Barr et al. 2007). Warming temperatures in the northern latitudes have lengthened the growing season, enhancing spring photosynthesis, but also increasing the lateseason respiration cost to net productivity; the spring productivity increase due to temperature increases was nullified by fall respiration costs (Piao et al. 2008). This lengthening of the growing season may also exacerbate the summer drought episodes illustrated in Fig. 1 as per the findings of Sacks et al. (2007) and those of Bergh et al. (2003). Increases in temperature in non-waterlimiting conditions may also increase decomposition of litter. This process releases nutrients, a positive effect on productivity, but also reduces the amount of carbon stored in forest soils, a carbon reserve of great importance in middle and northern latitudes. The complex response of forests to elevated temperatures and precipitation may cause an increase in the carbon exchanged between the atmosphere and the biosphere without necessarily an increase in Net Primary Productivity (NPP) or Net Ecosystem Productivity (NEP) as Körner et al. (2005) found for sites in elevated $\mathrm{CO}_{2}$ conditions. Forests may churn over more carbon through turnover and decomposition but not necessarily store more, even if growth is enhanced. Winter temperatures and snow pack depths also alter respiration levels (Monson et al. 2006b). Forests' physiological responses to environmental changes are highly dependent on the characteristics of the particular forested site.

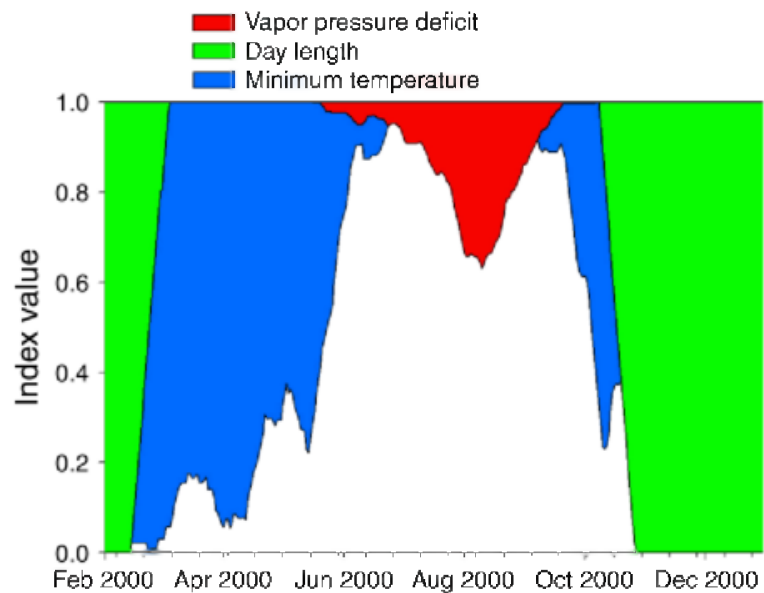

FIG. 1. A conceptual summary of the theoretical mix of seasonal growing-season constraints for Missoula, Montana, in the year 2000 . Index values from 0 to 1 represent $100 \%$ constraints to no constraints on growth, and the colors above the curve represent the source of the constraints (vapor pressure deficit, day length, and minimum temperature). This conceptual analysis can be done for any site from standard daily weather records (Jolly et al. 2005).

The objective of this study was to understand the trade-offs between temperature and water controls on forested sites in the context of climate projections. Three scenarios of temperature and precipitation selected from the IPCC AR4 23 AOGCMs (Atmosphere-Ocean General Circulation Models) were input to a process model for key forested sites in the northern U.S. Rocky Mountains: a drier projection (GFDL-CM2.0), a median projection (PCM), and a wetter projection (CGM3.1(T63)). These scenarios are in the middle range of the IPCC AR4 23 AOGCMs. The northern U.S. Rocky Mountain region was selected for its range in elevation and annual precipitation on forested sites. With the model Biome-BGC (Thornton 1998a), a model that integrates well our current knowledge of forest processes and their interactions with environmental conditions, we projected six sites covering the range of conditions in the region, under each scenario. All three temperature and precipitation scenarios were set under the same atmospheric $\mathrm{CO}_{2}$ concentration, as projected by the IPCC Special Report on Emission Scenarios (SRES) A1B (Nakicenovic et al. 2000).

\section{BACKGROUND AND DATA}

\section{Biome- $B G C$}

Biome-BGC is a model that simulates fluxes and storage of energy, water, carbon, and nitrogen for vegetation and soil components of terrestrial ecosystems (Thornton 1998b) (available online). ${ }^{2}$ The model was originally developed for forest biomes (Running and Gower 1991), and then expanded to other biomes

\footnotetext{
${ }^{2}$ (www.ntsg.umt.edu/models/bgc $\rangle$
} 
(Running and Hunt 1993, White et al. 2000). BiomeBGC simulates energy and water balances estimating snow accumulation and melting, drainage and runoff, soil and leaf surface evaporation, water transpiration through leaf stomata, leaf sunlight interception, and ground-level sunlight penetration. It also models biogeochemical cycles relating to plant growth and decomposition such as photosynthetic-carbon fixation, soil nitrogen uptake, carbon and nitrogen distribution throughout growing plant parts, new-leaf growth, and leaf litterfall, litter and organic matter decomposition, and plant mortality. Biome-BGC is a member of a class of ecosystem process models sometimes referred to as "big-leaf" models: it treats the landscape canopy as a single leaf layer with a given thickness and is neither individual based nor species specific. Instead, it uses site conditions, vegetation physiological characteristics, and meteorological data to simulate ecosystem changes through time. The model is driven by climate and environmental changes and was developed to incorporate our present understanding of plant physiological responses to environmental changes. Biome-BGC has been extensively tested at a variety of scales ranging from point to global simulations (e.g., Churkina et al. 2003, Bond-Lamberty et al. 2005, Qian et al. 2006, Mu et al. 2008).

Weather is the most important control on vegetation processes in Biome-BGC. Flux estimates depend strongly on daily weather conditions. Model behavior over time depends on the long-term patterns of these weather conditions, the climate. The model requires a set of initial conditions from which to start a simulation. These conditions are established through a spin-up simulation that can span many thousands of years until the system reaches a steady state with respect to soil carbon fluxes. The compartment $\mathrm{C}$ and $\mathrm{N}$ values reached at this steady state are used as starting values for further simulations. Our spin-up simulations were based on actual meteorological data from 1950 to 2005 , which we recycled throughout the spin-up years, along with site-specific plant ecophysiology information and site conditions, such as soil depth and geolocation.

\section{Climate projections}

While climate models unavoidably simplify the complex interactions between components of the Earth's system, increases in computing capability of recent decades have led to models based on wellestablished physical principles that are capable of reproducing observed features of recent climate (Randall et al. 2007) and past climate changes (Jansen et al. 2007). (AOGCMs) are the primary source of regional information on the range of possible future climates (Christensen et al. 2007). The IPCC AR4 support AOGCMs as credible quantitative estimates of possible future climate change, particularly at continental and larger scales. The precise boundaries between regions of robust increase and decrease in temperatures and precipitation remain uncertain, and these boundaries are commonly where AOGCM projections disagree (Christensen et al. 2007). Confidence in these estimates is higher for some climate variables than for others (e.g., temperature vs. precipitation [Randall et al. 2007]). Because of the importance of precipitation in forests such as the ones in the northern U.S. Rocky Mountain region, we selected three models from the 23 used in the AR4 that varied in their precipitation projections: CGM3.1(T63) model, from the Canadian Centre for Climate Modelling and Analysis, the PCM, from the National Center for Atmospheric Research (NCAR), and the GFDL-CM2.0, from the U.S. Department of Commerce/NOAA Geophysical Fluid Dynamics Laboratory. As shown in Fig. 2, the selected models were not marginal ones; their precipitation projections were near the center of the distribution of AOGCM projections.

For each AOGCM, average monthly changes in values of precipitation and temperature from a base period (years 1980-1999) to 2030 (2020-2039), and from the base period to 2080 (2070-2089), were provided by the National Center for Atmospheric Research (NCAR) (Table 1) for an area $\sim 5.6^{\circ}$ in latitude and longitude over the northern U.S. Rocky Mountains (Fig. 3). The 2030 values represent the average change, per month, between 2020 and 2039, and the 2080 values represent the average change, per month, between 2070 and 2089. As per the application instructions on the use of these projections, these averages were applied to monthly precipitation and temperature values from 1980 to 1999. The probability distribution functions (PDF) of these three AOGCMs in a Bayesian synthesis of all AOGCMs are presented elsewhere (Tebaldi et al. 2005). Projections from these three AOGCMs were completed under the A1B emission scenarios (Nakicenovic et al. 2000), which for our purposes, provide an atmospheric $\mathrm{CO}_{2}$ concentration for our simulation horizon.

Monthly temperatures and precipitation predictions from CGM3.1(T63), PCM, and GFDL-CM2.0 under SRES scenario A1B (Table 1) were the basis for the three scenarios under which we explored the temperature and precipitation trade-offs in forests of the northern U.S. Rocky Mountains. The climate change scenarios do not account for local differences, such as the differences in climate change according to altitude or on the leeward and windward side of mountains. The selected AOGCMs differ in their precipitation and temperature projections only. A quantitative comparison of the three AOGCM precipitation and temperature projections to recent temperatures and precipitation levels (1980-1999) is presented in Table 1. Differences in temperatures are in degrees centigrade, and differences in precipitation are in percentages. In a general annualbased comparison to present-day climate, CGM3.1(T63) is the wettest model for both the 2030 and the 2080 change periods, and is much wetter than present-day climate; GFDL-CM2.0 is the driest (much drier than 


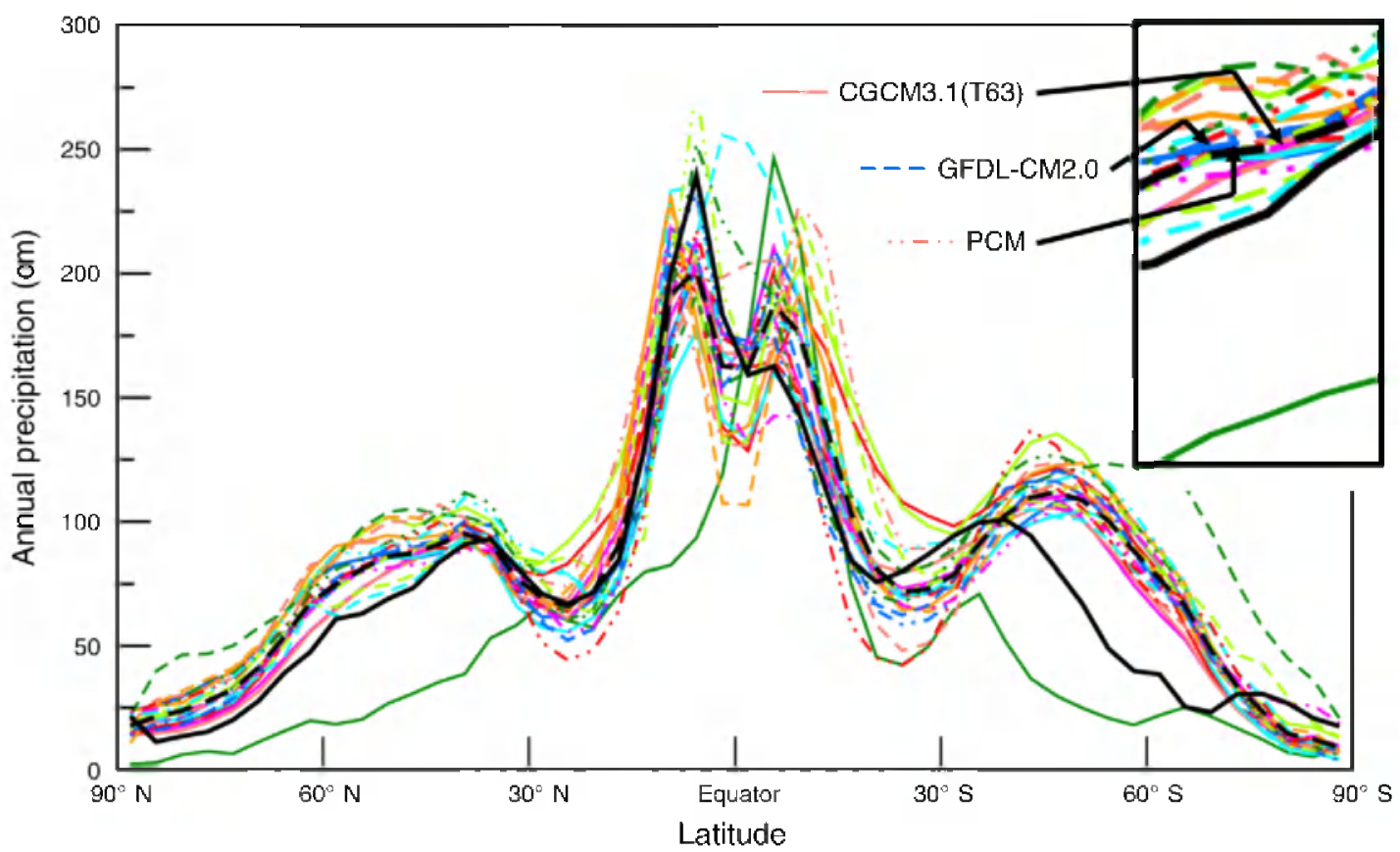

FIG. 2. The large panel shows observed annual mean precipitation averaged by latitude zones from 1980 to 1999 (continuous black line), simulated annual mean precipitation (colored lines), and all model averages annual mean precipitation (black dashed line) for the 23 Atmosphere-Ocean General Circulation Models (AOGCMs) used in the IPCC AR4. The smaller inset shows the location of the three AOGCMs selected for climate projections in this study (Wet, CGM3.1(T63); Dry, GFDL-CM2.0; Middle, PCM) amid the 23 models for latitudes between $41^{\circ} \mathrm{N}$ and $48^{\circ} \mathrm{N}$, our approximate study area.

present-day climate) in both the 2030 and 2080 periods; and PCM is very similar to present-day total precipitation quantity in the 2030 period, although a little wetter, and mostly wetter than present day in the 2080 period. All three AOGCMs are warmer than present-day climate, with GFDL-CM2.0 being much hotter than present-day climate in the 2030 change period, and very hot in comparison with present-day climate in the 2080 change period. CGM3.1(T63) is warmer than presentday climate in both change periods, and PCM is a little warmer than the present-day climate in 2030 and warmer than the present-day climate in the 2080 change period. GFDL-CM2.0 distinguishes itself from the two other models, as it is much hotter and drier than our present climate. CGM3.1(T63), PCM, and GFDLCM2.0 are referred to as wet, middle, and dry, respectively, in this text. Note that on a seasonal basis, there is much more variation between models than in the above annual general description.

\section{Sites}

Six sites were strategically selected to represent climate niches across the wide range of elevation and historical precipitation in the northern U.S. Rocky Mountain region. Sites representing a range of elevation (a strong surrogate for temperature in mountainous terrain) and precipitation levels are listed in Table 2, along with their annual, winter, and summer average temperatures. Annual precipitation levels among the sites ranged from $30 \mathrm{~cm} /$ year to $192 \mathrm{~cm} /$ year between 1950 and 2005. Selected sites were: the city of Boise, Idaho, at $857 \mathrm{~m}$ elevation, representing a grasslandforest ecotone; Deer Point weather station, located in the mountains northeast of the city of Boise at $2147 \mathrm{~m}$ (high-elevation dry site); Priest River, Idaho, at $725 \mathrm{~m}$ (low-elevation wet site); the Summit weather station in Glacier National Park, Montana (see Plate 1), at $1600 \mathrm{~m}$ (high-elevation wet site); a station in Missoula, Montana, at $1042 \mathrm{~m}$ (low-elevation dry site); and the Tower Falls weather station in Yellowstone National Park, Wyoming, at $1909 \mathrm{~m}$ (high-elevation dry site) (Fig. 3). Each site corresponds to National Climatic Data Center (NCDC) weather stations.

\section{Biome-BGC input}

Biome-BGC requires meteorological data, site characteristics information, and ecophysiological data to simulate biomes through time. For each site, complete daily climate records were constructed from 1950 to 2005 using NCDC data. Daily surface records from NCDC for any climate station are rarely complete; hence, to construct complete daily records, we used a combination of adjacent climate station data modified to fit the target station characteristics (aspect, elevation, etc.) using the single-point bioclimatology model, MTCLIM (Mountain Climate Simulator [Thornton and Running 1999]), as well as DAYMET, a model that generates daily surfaces of temperature, precipitation, 
TABLE 1. Temperature and precipitation predictions for three Atmosphere Ocean General Circulation Models (AOGCMs) under emission scenario A1B (Nakicenovic et al. 2000) provided by the National Center for Atmospheric Research (NCAR).

\begin{tabular}{|c|c|c|c|c|c|c|}
\hline \multirow[b]{2}{*}{ Date } & \multicolumn{2}{|c|}{ Wet CGM3.1(T63) } & \multicolumn{2}{|c|}{ Middle PCM } & \multicolumn{2}{|c|}{ Dry CGDL-CM2.0 } \\
\hline & Precipitation (\%) & Temperature $\left({ }^{\circ} \mathrm{C}\right)$ & Precipitation $(\%)$ & Temperature $\left({ }^{\circ} \mathrm{C}\right)$ & Precipitation $(\%)$ & Temperature $\left({ }^{\circ} \mathrm{C}\right)$ \\
\hline \multicolumn{7}{|c|}{$2030(2020-2039)$} \\
\hline January & -15.99 & 1.21 & -2.33 & 0.99 & -6.51 & 0.32 \\
\hline February & 23.16 & 1.93 & 4.43 & 0.77 & -10.87 & 1.37 \\
\hline March & 13.28 & 1.21 & 0.75 & 0.73 & 1.19 & 1.95 \\
\hline April & 11.63 & 0.85 & -0.12 & 0.47 & 11.8 & 1.03 \\
\hline May & 21.03 & 1.44 & 7.41 & 0.79 & 1.62 & 0.21 \\
\hline June & 18.01 & 0.61 & 7.99 & 0.83 & -17.7 & 0.15 \\
\hline July & -2.92 & 0.88 & -4.43 & 1.11 & -32.36 & 3.17 \\
\hline August & 15.95 & 0.44 & 3.92 & 0.9 & -47.88 & 3.51 \\
\hline September & 9.26 & 0.01 & -17.01 & 1.28 & 0.38 & 1.68 \\
\hline October & 17.15 & 1.1 & 13.87 & 0.8 & -3.71 & 1.95 \\
\hline November & 22.37 & 0.49 & -3.92 & 0.55 & 0.81 & 1.51 \\
\hline December & 22.83 & 1.71 & -4.19 & 1.03 & -1.82 & 1.2 \\
\hline \multicolumn{7}{|c|}{$2080(2070-2089)$} \\
\hline January & 4.52 & 3.38 & 6.95 & 3.84 & -10.69 & 3.34 \\
\hline February & 37.3 & 4.4 & 14.12 & 3.6 & 6.6 & 4.61 \\
\hline March & 24.66 & 2.58 & 9.35 & 1.64 & 14.44 & 3.98 \\
\hline April & 36 & 2.58 & 10.85 & 1.51 & 19.35 & 2.98 \\
\hline May & 20.94 & 3.33 & 11 & 1.6 & 2.38 & 2.1 \\
\hline June & -6.83 & 2.85 & 11.79 & 2.5 & -26.66 & 2.83 \\
\hline July & -9.16 & 3.08 & -4.9 & 2.97 & -50.35 & 7.5 \\
\hline August & -7.66 & 2.44 & 8.13 & 2.82 & -47.16 & 8.52 \\
\hline September & 16.7 & 2.5 & -29.77 & 3.3 & -40.71 & 5.48 \\
\hline October & 13.25 & 3.04 & 12.96 & 2.26 & -18.14 & 4.28 \\
\hline November & 36.41 & 1.1 & 1.46 & 1.99 & 6.71 & 3.68 \\
\hline December & 23.48 & 3.93 & -3.9 & 2.72 & 31.55 & 3.25 \\
\hline
\end{tabular}

Notes: For each model, monthly changes in values of precipitation and temperature from a base period (years 1980-1999) to 2030 (average change between 2020 and 2039), and from the base period to 2080 (average change between 2070 and 2089) were provided by NCAR for an area $\sim 5.6^{\circ}$ in latitude and longitude in the northern U.S. Rocky Mountains. For projections [CGM3.1(T63) and others] see Introduction.

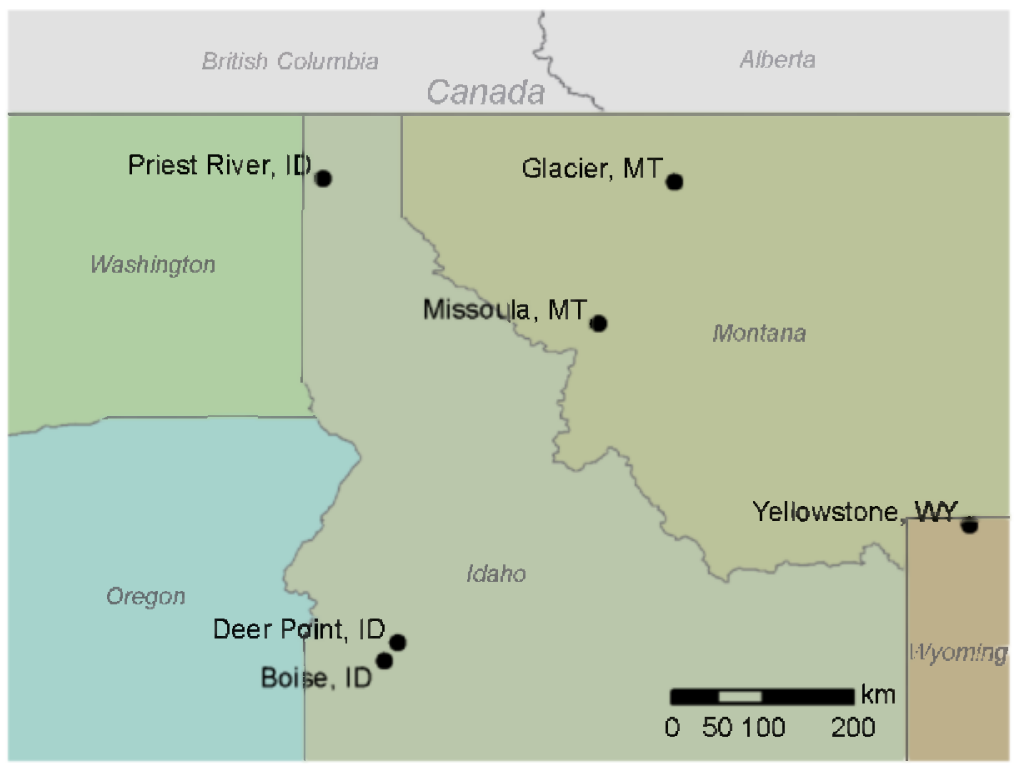

FIG. 3. The region referred to as the northern U.S. Rocky Mountains for the purposes of our study. The models' grids were interpolated by NCAR to a "T42" grid, which represents the median resolution among the models contributing to the Program of Climate Models Diagnostic and Interpretation (PCMDI) archive (Tebaldi et al. 2005). Black dots represent the six climate niche sites selected for analyses. 
TABLE 2. Elevation, annual, winter, and summer average temperatures (1950-2005) for sites selected as representative of climate niches in the forests of the northern U.S. Rocky Mountains.

\begin{tabular}{lccrcr}
\hline \hline & & & \multicolumn{3}{c}{ Temperature $\left({ }^{\circ} \mathrm{C}\right)$} \\
\cline { 3 - 6 } \multicolumn{1}{c}{ Sites } & Elevation $(\mathrm{m})$ & Precipitation $(\mathrm{cm})$ & Yearly & Winter & Summer \\
\hline Boise & 857 & 30 & 14 & 2 & 26 \\
Missoula & 1042 & 44 & 10 & -1 & 22 \\
Yellowstone & 1909 & 46 & 6 & -6 & 18 \\
Deer Point & 2147 & 49 & 9 & -2 & 21 \\
Priest River & 725 & 81 & 10 & -1 & 21 \\
Glacier & 1600 & 107 & 5 & -5 & 16 \\
\hline
\end{tabular}

humidity, and radiation over large regions of complex terrain (available online). ${ }^{3}$

Using the monthly values of each AOGCM for each of the two time periods combined with actual climate data from 1950 to 2005, we constructed a time series of daily precipitation and temperature from 1950 to 2089. Conforming to AOGCM development, daily data from 1980 to 1999 for our six selected sites were used as a base period to which changes in precipitation and temperature for 2030 (2020-2039) and 2080 (2070-2089) were applied. Linear interpolation of monthly precipitation and temperature values between 2005 and 2020, and between 2039 and 2070, were combined with daily to monthly variation from the last 15 and 30 years, respectively, of actual data (1992-2005 and 1976-2005) to complete the time series.

$\mathrm{CO}_{2}$ levels, required as input to Biome-BGC, matched levels specified in the IPCC SRES A1B. Biome-BGC version 4.2 was used to project evergreen needle forests growing on our six sites, with adjustments to site characteristics and ecophysiological parameters to suit each site, from 1950 to 2089 under each AOGCM, creating three projections of each of the six sites. Spinup runs of Biome-BGC (i.e., model runs over extended time periods) were used to provide the initial $1950 \mathrm{C}$ and $\mathrm{N}$ state for each site. Soil inputs were generated using State Soil Geographic (STATSGO) data, which provide 8 -km soil data sets, compiled by the Natural Resources Conservation Service (NRCS) (available online). ${ }^{4}$ Soil data were extracted based on the latitude and longitude for each site from STATSGO data. Industrial N deposition values were set at $0.0004 \mathrm{~kg} \mathrm{~N} \cdot \mathrm{m}^{-2} \cdot \mathrm{yr}^{-1}$.

\section{Analysis}

We first examined the climate trends, comparing temperature and precipitation differences between present averages (1996-2005) and end of projections averages (2080-2089). We then looked at specific water- and temperature-driven trends by quantifying differences in snow pack, growing-season length, and number of water stress days between AOGCMs across sites and between sites. We defined a water stress day as a day on which soil water potential falls below -1 MPa. Soil moisture is a key

\footnotetext{
${ }^{3}\langle$ http://www.daymet.org/〉 [Thornton et al. 1997]

${ }^{4}\langle$ http://soils.usda.gov/survey/geography/statsgo/ $\rangle$
}

link between climate fluctuations and physiological processes (Rodriguez-Iturbe 2000). Canopy conductance is strongly related to water potential in the upper soil layer, especially once soil water potential decreases below a threshold (e.g., Oren et al. 1998). The general soil water potential at which stomata close for northern U.S. Rocky Mountain conifers is around $-1.5 \mathrm{MPa}$ (Carter et al. 1988), often referred to as the wilting point; however, living cells in a tree remain relatively turgid even in drought conditions (Waring and Running 2007). Our threshold was selected to represent days with water stress conditions for these forests (Carter et al. 1988). The water resources of the western U.S. depend heavily on snow pack to store part of wintertime precipitation for use in the drier summer months (Hu et al. 2009). We looked at both the number of days with snow on the ground and the timing of the maximum amount of snow on the ground (peak snow) for each hydrological year (1 October to 30 September). The concept of a growing season can be defined in many ways, all of which are arbitrary, since a growing season is more of a continuum than a discrete event (Jolly et al. 2005), especially in conifer forests. For the purpose of this study, a constant definition was needed to provide a comparison point between the different time periods and different projections of climate. We defined the beginning of the growing season as the first period of more than seven consecutive days with $>30 \%$ of the average maximum annual photosynthesis between 1950 and 2005, and the end as the first period of more than seven days of photosynthesis below that threshold.

Finally, we completed the analyses by comparing carbon fluxes, such as NPP and NEP, and actual carbon on site. NPP is a carbon flux defined as the photosynthesis of the system minus the respiration of primary producers (Chapin et al. 2006). It is but one part of the Net Ecosystem Production (NEP), which takes into account heterotrophic respiration. NEP can essentially be viewed as the accumulation (or loss) of carbon over a whole ecosystem and over a whole season or other time period (IPCC 2003), while NPP can be viewed as the amount of carbon fixed by plants after accounting for their respiration losses, usually over a year or a growing season. NPP and NEP are useful measures of carbon at an ecosystem or forest stand level. Net Primary Production (NPP) has been shown to correlate positive- 
ly with precipitation levels (Knapp and Smith 2001, Kang et al. 2006), with soil moisture being the link between precipitation and forest productivity (Weltzin et al. 2003). An analysis of the effects of the different climate scenarios on ecosystem-level carbon in the different forests of the northern U.S. Rocky Mountains was completed by comparing differences in these measurements with changes in total site carbon between sites and AOGCMs.

\section{Results AND Discussion \\ Climate trends}

Our constructed daily climate time series (1950-2089), used as input to Biome-BGC, yielded annual average daily temperatures in Deer Point of $17^{\circ} \mathrm{C}$ vs. $8^{\circ} \mathrm{C}$ in Glacier, and average annual precipitation values from $111 \mathrm{~cm}$ in Glacier to $32 \mathrm{~cm}$ in Boise. The time series differentiated well between the sites, where drier sites such as Boise, Missoula, and Yellowstone were indeed drier, and higher-elevation sites (Deer Point, Glacier, and Yellowstone) were colder. Fig. 4 shows averaged total annual precipitation for recent-times simulations (1996-2005) and for the end of the projections (20802089) and averaged maximum and minimum temperature differences by season for the same time periods (positive values $=$ increase, while negative values $=$ decrease). From this comparison, we can see that all sites received more precipitation on average at the end of the projections than present-day averages. Compared with present-day average temperatures, all temperatures increase by the end of the projection, with winter temperatures (both maximum and minimum) increasing more than other seasons.

\section{Temperature- and water-driven trends}

Based on the linear model of the total number of annual growing-season days (GS) across the time series (1950-2089), we calculated the difference between the predicted length of the growing season in 1950 and that predicted in 2089. Table 3 lists these differences per site by AOGCM. The total growing-season length showed a significant increasing linear trend for all sites and all models, except for Yellowstone under the dry climate projections, where the growing-season length showed no significant trend. Under all three projections, the growing-season length in Boise changed the most (increases of 50, 35, and 43 days in the wet, middle, and dry projections, respectively), with Glacier showing the least change $(19,15$, and 17 more days of growing season under the wet, middle, and dry projections, respectively). In our projections, by $2005, \sim 40 \%$ of this change has already occurred.

The same linear model calculations revealed that under all AOGCM projections and SRES A1B, between 1950 and 2089 across sites, not only does growingseason length (GS) increase, but the number of days with snow on the ground (SW) decreases, and the number of water stress days (WS) increases, all with significant linear trends (e.g., Fig. 5). Average changes in growing season, snow water, and water stress by AOGCM across sites are shown in Table 4. As for the growing-season change, by 2005, projections show that around $40 \%$ of change in SW and WS has already occurred.

When we compared the number of water stress days between 1950 and 2089, where there is a significant linear model, the high-elevation dry site (Deer Point) increased the most, with 86 more water stress days by 2089 under the wet AOGCM projections and 91 more days under the dry AOGCM projections; and Priest River increased the least, with 37 and 48 more water stress days by 2089 as compared with 1950 , under the wet and dry projections, respectively. A little less than half of this change had already happened by 2005 . The number of days when water potential of soil and leaves was less than $-1 \mathrm{MPa}$ between 1950 and 2005 (the projection period based on actual data) showed no significant linear increase, and the number of days of water stress predicted by each AOGCM scenario between 2006 and 2089 differed very little between models. Hence, we compared the number of water stress days above the long-term average from 1950-2005, across all AOGCMs, in the 1950-2005 time period to the number in the 2006-2089 time period (Fig. 6). Across all sites, the number of water stress days increased by an average of 47 days.

For five out of six sites, peak snow occurs earlier by the end of the projection (2089) than it did at the beginning (1950). According to a linear model across the time series (1950-2089) and across all AOGCMs, peak snow occurred 29 days earlier, on average, for five of the sites, with peak snow occurring 54 days earlier at the high-elevation dry site (Deer Point), 7 days earlier at the forest-grassland ecotone site (Boise), 41 days earlier at the high-elevation wet site (Glacier), 10 days earlier at the lower-elevation dry site (Missoula), and 31 days earlier at the low-elevation wet site (Priest River) by the end of the projection vs. the beginning. Fig. 7 shows the average timing of peak snow according to a linear model of all the peak snow estimates from AOGCM projections for the high-elevation wet site (Glacier), and the high-elevation dry site (Deer Point). Peak snow in Deer Point goes from 14 February 1950 to 23 December 2089 (2 February in 2005), and from 8 April 1950 to 25 February 2089 (2 April in 2005) for Glacier. The importance of snow pack water storage in the mountainous West is well known (Sheffield et al. 2004). Up to $75 \%$ of all stream water originates from snowmelt. Further, the role that cold-season processes play in the development of summer drought and fire risk cannot be underestimated (Service 2004). Our projections follow the already well-documented shift toward earlier runoff in recent decades attributed to more precipitation falling as rain instead of snow, and earlier snowmelt (Knowles et al. 2005, Hu et al. 2009). Our simulations support a continuation of these trends with, on average, one 


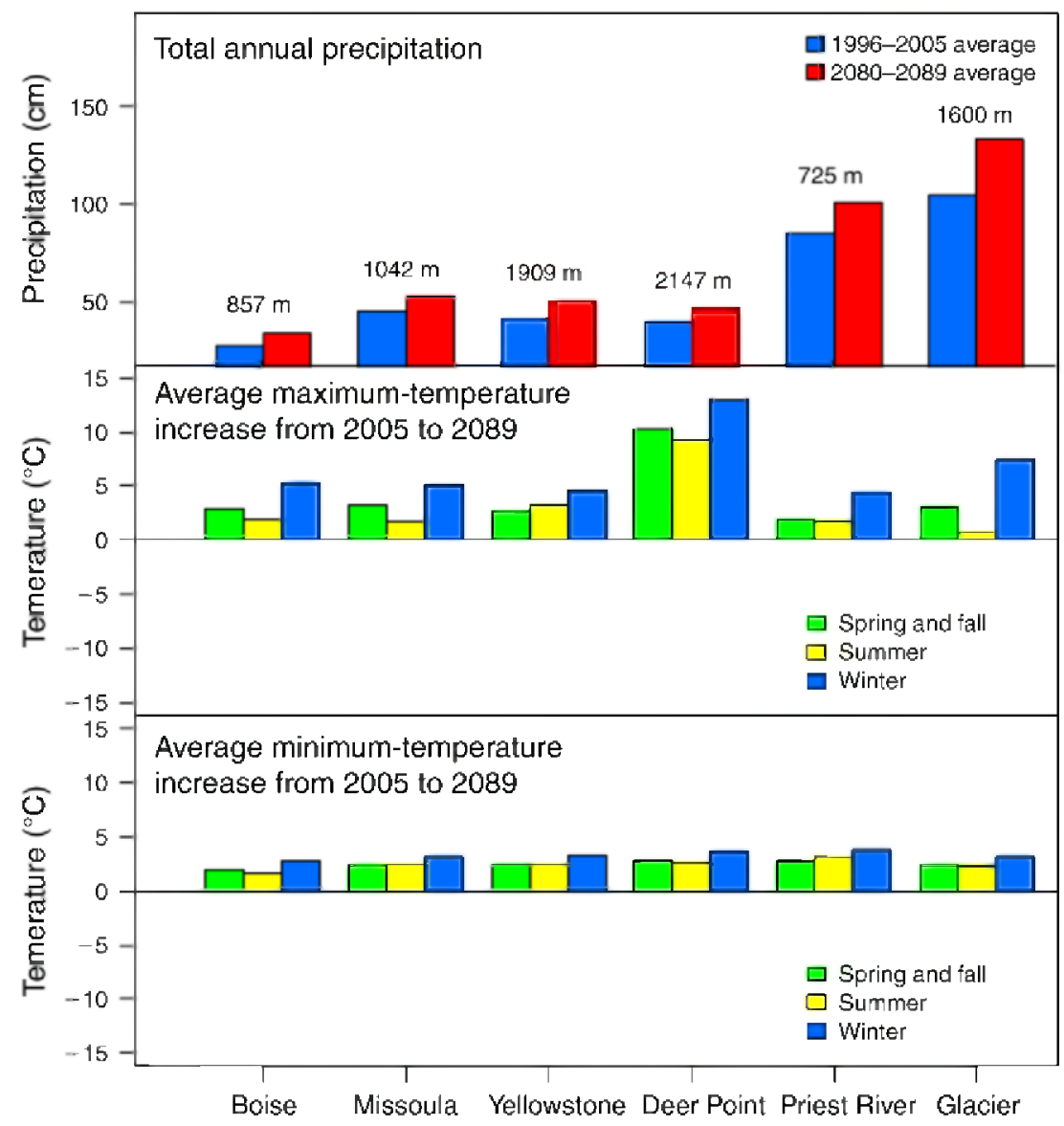

FIG. 4. A comparison of predicted total yearly precipitation, average maximum, and average minimum temperatures by season between the present-day average (1996-2005) and the end of the simulations (2080-2089) under CGM3.1(T63) Atmosphere-Ocean General Circulation Model temperature and precipitation projections for sites across the northern U.S. Rocky Mountains. Elevations of the sites appear above the bars in the top graph.

month earlier peak snow across all sites and significant negative linear trends in the number of days per year with snow on the ground. As per Hu et al.'s (2009) compilation of nine years of flux tower data at Niwot Ridge, Colorado (a similar high-elevation dry site just south of our study area), our simulation predicts that less snow will likely increase the summer drought period, further increasing the number of water stress days. At the dry sites that presently depend on their spring snow pack to maintain a forest canopy during summer months, our simulations indicate that by 2089 under all three GCM projections, there would be very little to no snow pack left on these sites. As an example, Boise, Idaho, a site representing the ecotone between forests and grasslands, had an average of 27 days with snow on the ground between 1950 and 2005 (ranging from 84 to 4 days).

The increase in growing-season length in our simulations combined with a decrease in the number of days with snow on the ground and the earlier peak snow seems to have resulted in an increase in water stress across all sites under all projections, a finding already supported by recent compilations of flux tower data (Monson et al. 2002, Hu et al. 2009).

\section{Carbon}

Carbon accumulation and carbon fluxes also responded to the climate projections, but unlike growing season,

TABLE 3. Difference between the 2089 and the 1950 average growing season length (from a linear model) by AOGCM (wet, middle, dry) for six forested sites across the northern U.S. Rocky Mountains and the average (across AOGMCs) linear model value for 2005 .

\begin{tabular}{lcccc}
\hline \hline \multirow{2}{*}{ Sites } & \multicolumn{3}{c}{ AOGCM } & Average 2005 \\
\cline { 2 - 4 } & Wet & Middle & Dry & GS length \\
\hline Deer Point & 33 & 20 & 30 & 115 \\
Boise & 50 & 35 & 43 & 136 \\
Glacier & 19 & 15 & 17 & 144 \\
Missoula & 41 & 34 & 27 & 151 \\
Priest River & 21 & 15 & 22 & 150 \\
Yellowstone & 20 & 14 & NS & 113 \\
\hline
\end{tabular}

Note: AOGCMs are Atmosphere-Ocean General Circulation Models. 


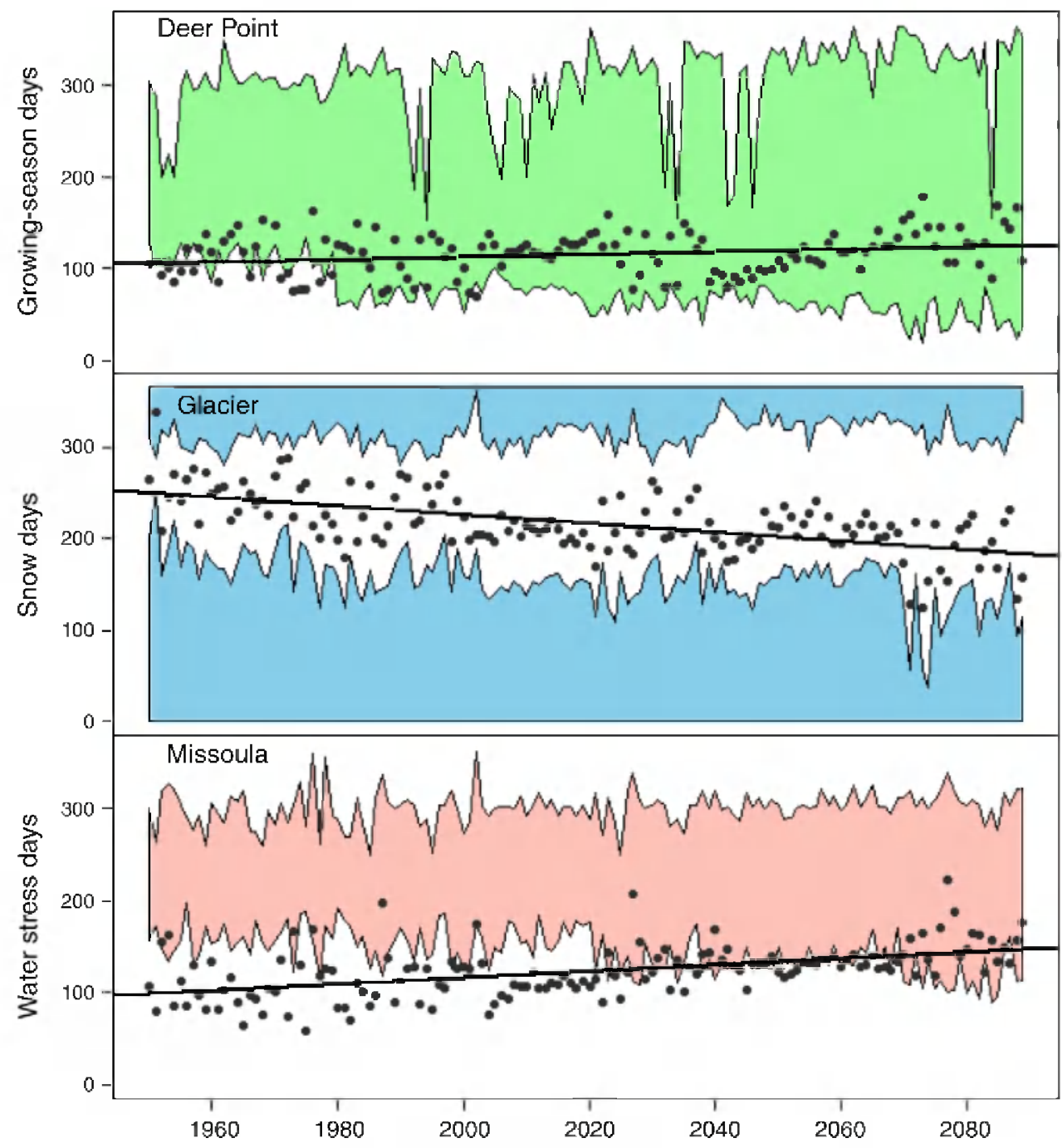

FIG. 5. Examples of time series of the three key variables with clear responses for a high-elevation dry site (Deer Point), a highelevation wet site (Glacier), and a lower-elevation dry site (Missoula) in the northern U.S. Rocky Mountains. The shaded areas show the timing of the growing season (green), the presence of snow (blue), and water stress (pink) for the year ( $y$-axis is from 1 to 365 [days]) throughout the simulation horizon ( $x$-axis; 1950-2089); the data points (solid circles) are the total number of days of growing season, snow presence, and water stress, respectively, and the lines indicate a fitted linear model through these totals.

snow pack, and water stress, responses differed between AOGCMs. For most sites under all three climate projections there is an increase in average NPP, except for Glacier under the dry projection. Fig. 8 shows the differences in projected recent average NPP (1996-2005) and the end of the projections (2080-2089). The increase is much more pronounced under the wet climate projections for all sites between now and the end of the projections. Yellowstone (high-elevation dry site) increased the most in NPP of all sites across all projections. NPP increased less under the middle climate projection than the wet projection (for all sites). Under the dry projection, the high-elevation wet site (Glacier) shows a decrease in NPP between recent rates and the end of the projections, and the low- and high-elevation dry sites (Missoula, Yellowstone, and Deer Point), as
TABLE 4. Average number of days of change in growing season length, of change in the number of days with snow on the ground, and of change in the number of water stress days, by AOGCM model (wet, middle, dry) across all sites, between 1950 and 2089 .

\begin{tabular}{|c|c|c|c|c|c|c|}
\hline \multirow[b]{2}{*}{ AOGCM } & \multicolumn{2}{|c|}{$\begin{array}{c}\text { Growing } \\
\text { season }\end{array}$} & \multicolumn{2}{|c|}{$\begin{array}{c}\text { Days } \\
\text { with snow }\end{array}$} & \multicolumn{2}{|c|}{$\begin{array}{l}\text { Water } \\
\text { stress }\end{array}$} \\
\hline & Average & SD & Average & SD & Average & SD \\
\hline Wet & 31 & 13 & -50 & 52 & 56 & 17 \\
\hline Middle & 22 & 10 & -54 & 51 & 60 & 17 \\
\hline Dry & 23 & 15 & -67 & 47 & 67 & 16 \\
\hline
\end{tabular}
Circulation Models. 


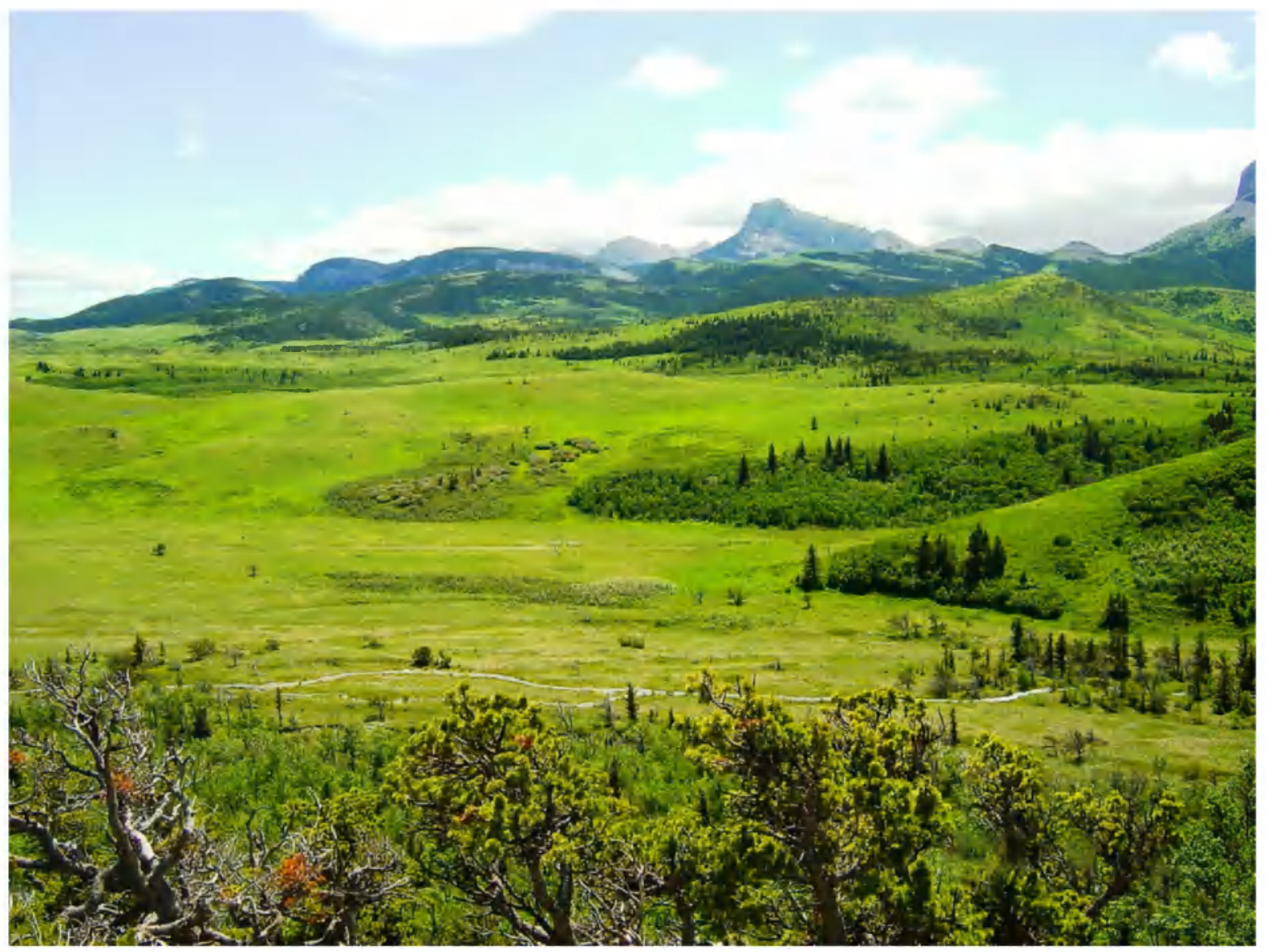

Plate 1. A springtime scene in early June on the eastern slope of the Rocky Mountains near Glacier National Park, Montana, USA. This study projects that, by the end of this century, snowmelt and spring greening will occur a month earlier than today in the northern Rocky Mountains of the United States. Photo credit: S. W. Running.

well as the low-elevation wet site (Priest River), show a small increase. Between the start of the simulations (1950-1959) and more recent NPP (1996-2005), Missoula, Priest River, and Yellowstone sites all showed a decrease in NPP while Deer Point, Boise, and Glacier had shown an increase.

An increase in growing-season length, as our simulation showed, has been associated with increases in productivity (e.g., Menzel et al. 2006), especially at latitudes where temperatures constrain productivity at certain times of the year, as is the case in our sites (see Fig. 1). Under non-water-limiting conditions, temperature is most likely a productivity driver for our sites as per the findings of Dang et al. (2007), Zhao and Zhou (2006), and White et al. (2006), who all identified temperature as a driver of productivity in their studies; however, the summer drought period intensified throughout the projections on our sites (as the increase in water stress days shows), limiting the potential positive effects of a longer growing season across our sites. The slight NPP increase could be due to the $\mathrm{CO}_{2}$ fertilization effect, similar to the findings of Vetter et al. (2005).

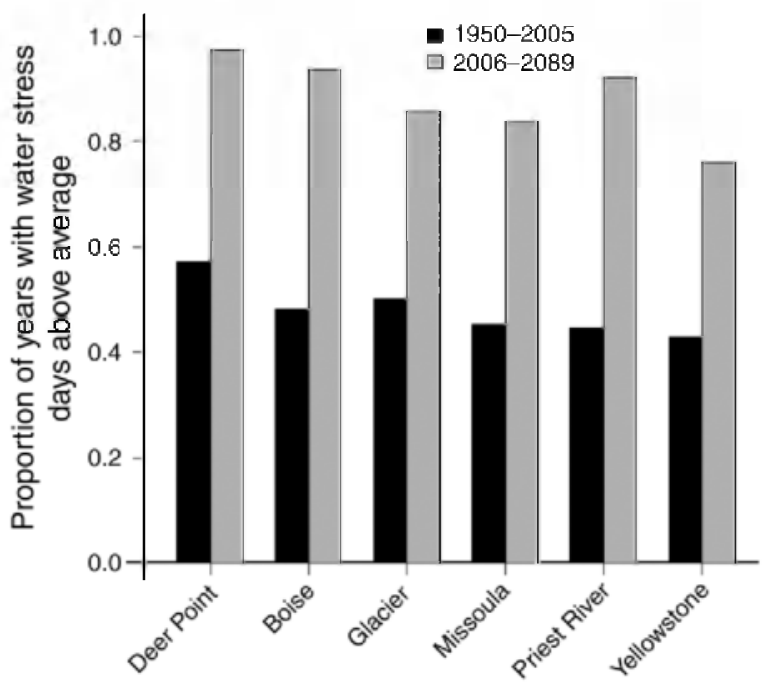

FIG. 6. The proportion of years where water stress (water potential of soil $<-1 \mathrm{MPa}$ ) is above the $1950-2005$ yearly average water stress days, for the 1950-2005 time period and for the 2006-2089 time period. Water potential of soil and leaves was modeled using Biome-BGC, while climate projections followed three Atmosphere-Ocean General Circulation Models under emission scenario A1B (IPCC AR4). 


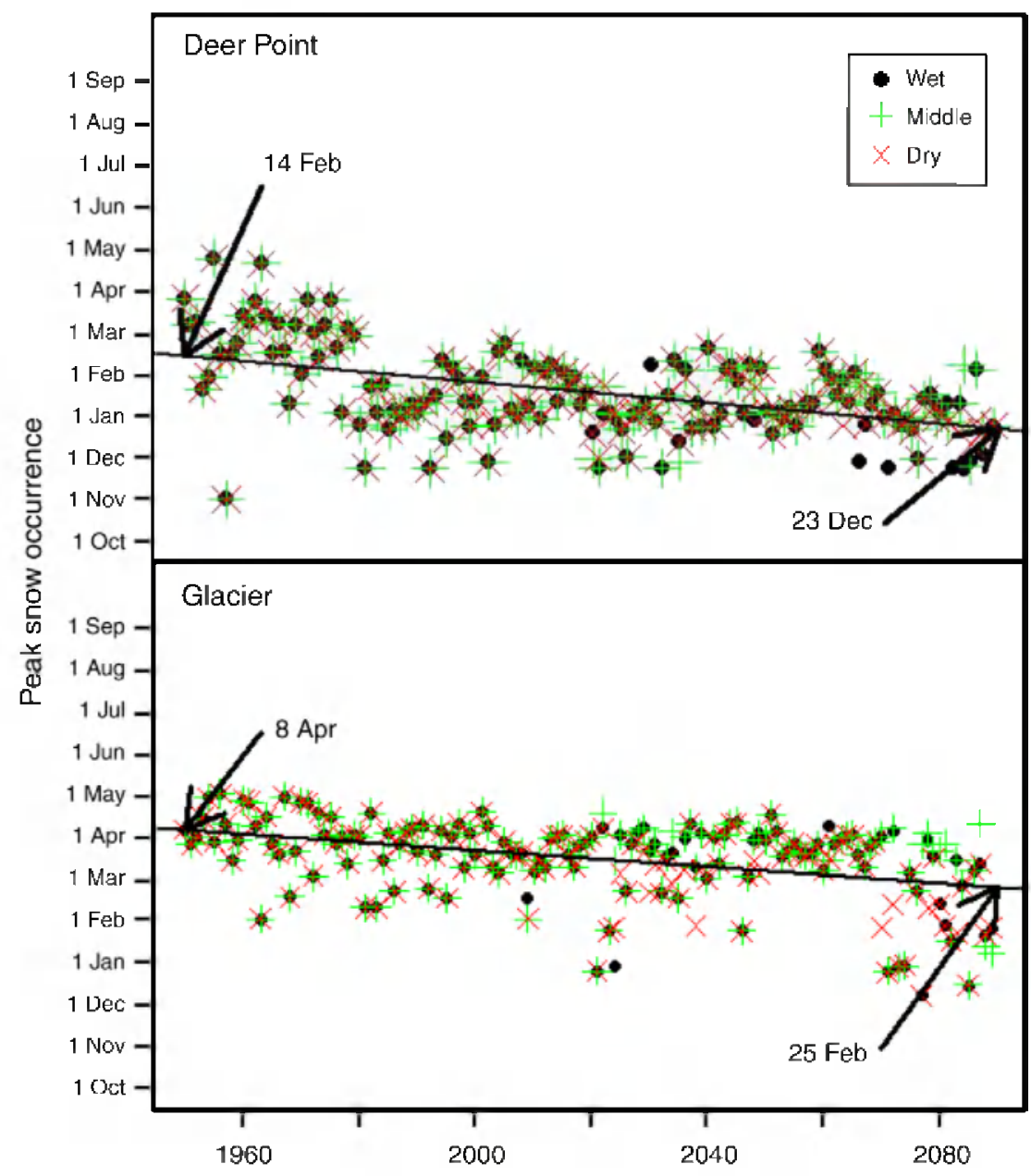

FIG. 7. Timing of peak snow based on meteorological data (1950-2005) and Atmosphere-Ocean General Circulation Model projections (2006-2089) for a high-elevation wet site (Glacier National Park, Montana) and a high-elevation dry site (Deer Point, Idaho). These sites represent high-elevation sites covering the moisture range, both of which show substantial changes in the occurrence of snow peak. For most data points, the symbols for wet, middle, and dry are superimposed. The arrows (ends of data lines) indicate the date of average peak snow at the beginning and the end of the projections.

Across all sites, on an individual-site basis, total site carbon under the dry projections lagged behind the wet and middle projections (Fig. 9); a water/temperaturedriven tipping point, past which system carbon declined, seems to exist. The dry AOGCM showed a decrease or stabilization of total carbon, while the other two scenarios showed increasing total carbon for all sites. The small range covered by our three AOGCMs (see Fig. 2) seemed to have crossed a temperature/water threshold past which the systems carbon accumulation begins a decline. Forests simulated with Biome-BGC do not stop growing unless a disturbance is simulated. Although the simulations incorporate background mortality, our simulated forests are without disturbances and are therefore expected to keep accumulating site level carbon. Our simulations show an accumulation of carbon at all sites between 1950 and 2005. This decline or stabilization of total carbon, as seen in Fig. 9, expresses a collapse of the system due to changed climatic conditions. At the high-elevation mountainous dry site (Deer Point) and at the grassland-forest ecotone site (Boise), projections show a regular spacing in carbon accumulation rate between projections, signaling a higher sensitivity to the represented range of precipitation and temperature; whereas, projections from the wet and middle AOGCMs were much more similar for the other sites, suggesting that the difference in temperature and precipitation between the wet and middle AOGCMs does not affect these sites as much. The most productive site, the high-elevation wet forests represented by Glacier, showed the greatest decline in total carbon accumulation under the dry projections, and both Glacier and Deer Point (representing the highelevation wet and the high-elevation dry forests of the northern U.S. Rocky Mountains, respectively) showed a decline in carbon accumulation under the dry climate projections. According to these projections (which match recent carbon analyses in forests of the moun- 
tainous west), if future precipitation and temperatures are similar to or drier than the dry scenario depicted here, high-elevation forests at both ends of the moisture spectrum of productivity would reduce their carbon accumulation. The significance of our results may be substantial given the increased importance of mountainous forest sites in the global carbon-cycle. (Note: recent analyses point to mountainous forests at high latitudes as being the "missing carbon sink" in the global carbon balance [Schimel et al. 2002]).

Flux tower data from Niwot Ridge reported similar carbon patterns (Monson et al. 2002, Sacks et al. 2007, $\mathrm{Hu}$ et al. 2009). At Niwot, lower rates of carbon accumulation were correlated with a decrease in gross productivity as opposed to respiration increases during the growing season; these conditions were also found in our projections (see Table 5). Data from a network of flux towers in Europe also reported that the accompanying drought stress, not high temperatures, caused the decline in productivity that followed the 2003 European summer drought (Reichstein et al. 2007). These observational findings support the pattern found in our projections. A small part of the productivity increase seen in some of our sites may be caused by temperature increases alone (as per Bergh et al. 2003) but the summer-drought effect combined with changes in snow dynamics seem to prevail. Phenotypic plasticity may potentially buffer the effects of changes in soil moisture regimes on productivity and thereby increase the resistance of ecosystems to reduced precipitation, but the potential for this buffering effect is not known (Weltzin et al. 2003) and we did not detect it in our results.

Net Ecosystem Productivity (NEP) values for the two projected time periods that matched the AOGCM projections (2020-2039 and 2070-2089) were used to calculate whether sites were carbon sources or carbon sinks during these time periods. Fig. 10 summarizes the data for each 20-year period. In Fig. 10, a positive value indicates the percentage of years in the 20 -year period that were carbon sinks, and a negative value the percentage of years that were carbon sources. From 2020 to 2039,3 of 6 sites were carbon sources with dryAOGCM climate projections, one with middle AOGCM, and none with wet AOGCM, while from 2070 to 2089,5 of 6 sites were carbon sources with dryAOGCM climate projections vs. 1 of 6 with the other AOGCMs. Forests even became carbon sources near the end of the time series under the hot/dry conditions projected by the dry AOGCM. This is similar to what Morales et al. (2007) predicted for European ecosystems by 2100 , but contrary to Bachelet et al. (2004), who project that a region including the northwestern Rockies will become a sink in the second half of the 21st century.

Carbon gain (or reduced carbon loss) can happen outside the traditional growing season, a time with temperatures below freezing and high snow accumulation (Anthoni et al. 1999). Substantial respiration can

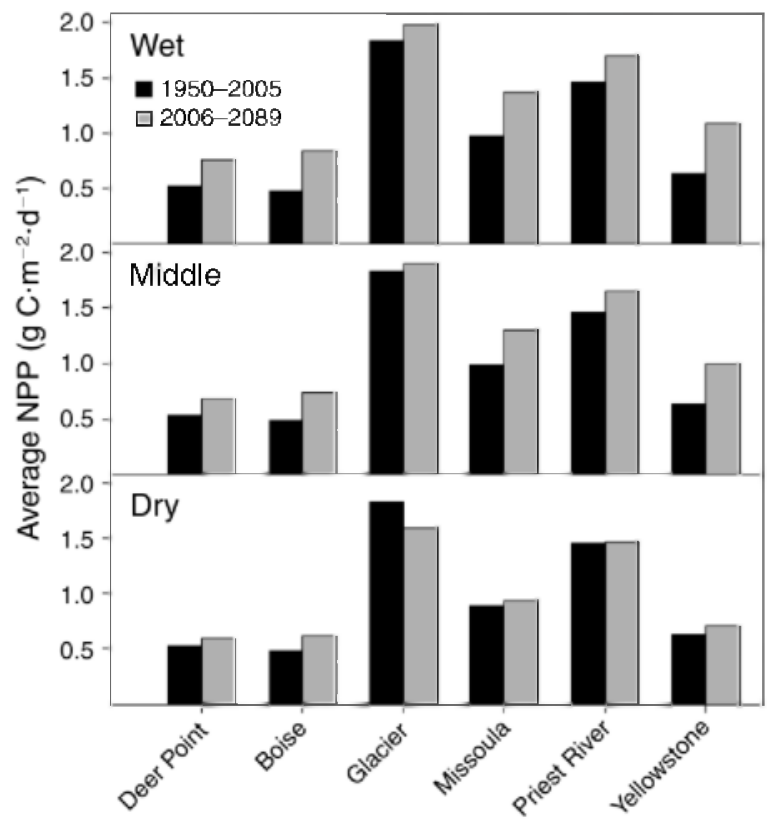

FIG. 8. Average NPP predicted by Biome-BGC for the 10 most recent years (1996-2005) and the last 10 years of simulations (2080-2089) for six northern U.S. Rocky Mountain sites under three Atmosphere-Ocean General Circulation Model climate projections.

occur under snow pack in winter, but reduced winter snow pack can also be accompanied by significantly lower rates of soil respiration (Monson et al. 2006a, Bergeron et al. 2007). NEP values in Fig. 10 were not constrained by our initial definition of growing season; they include year-round simulation of NEP. Winter respiration may therefore contribute to Glacier, our high-elevation wet site with a thick snow pack, becoming a carbon source sooner than the other sites. The balance between winter and summer temperatures, and snow pack and water available during the growing season, play an important role in determining if a site is a carbon source or sink. Our simulations, supported by data (Sacks et al. 2007), show the down regulation of high-elevation forests under cold and snowy conditions, making them a carbon source. The balance between carbon uptake and respiration is intricately tied to annual variations in temperatures and water availability; earlier snow melt due to increases in temperature and shallower snow packs may lower annual carbon uptake due to summer soil moisture limitation, but large winter snow packs and warm temperatures may also impact site carbon accumulation through increased respiration. Flux analysis in the Rockies and in boreal forests, as well as our simulations, have shown that snow pack and snow dynamics have a very important influence on site winter respiration, suggesting that a warmer climate may change soil carbon sequestration rates in forest ecosystems owing to changes in the depth of the 

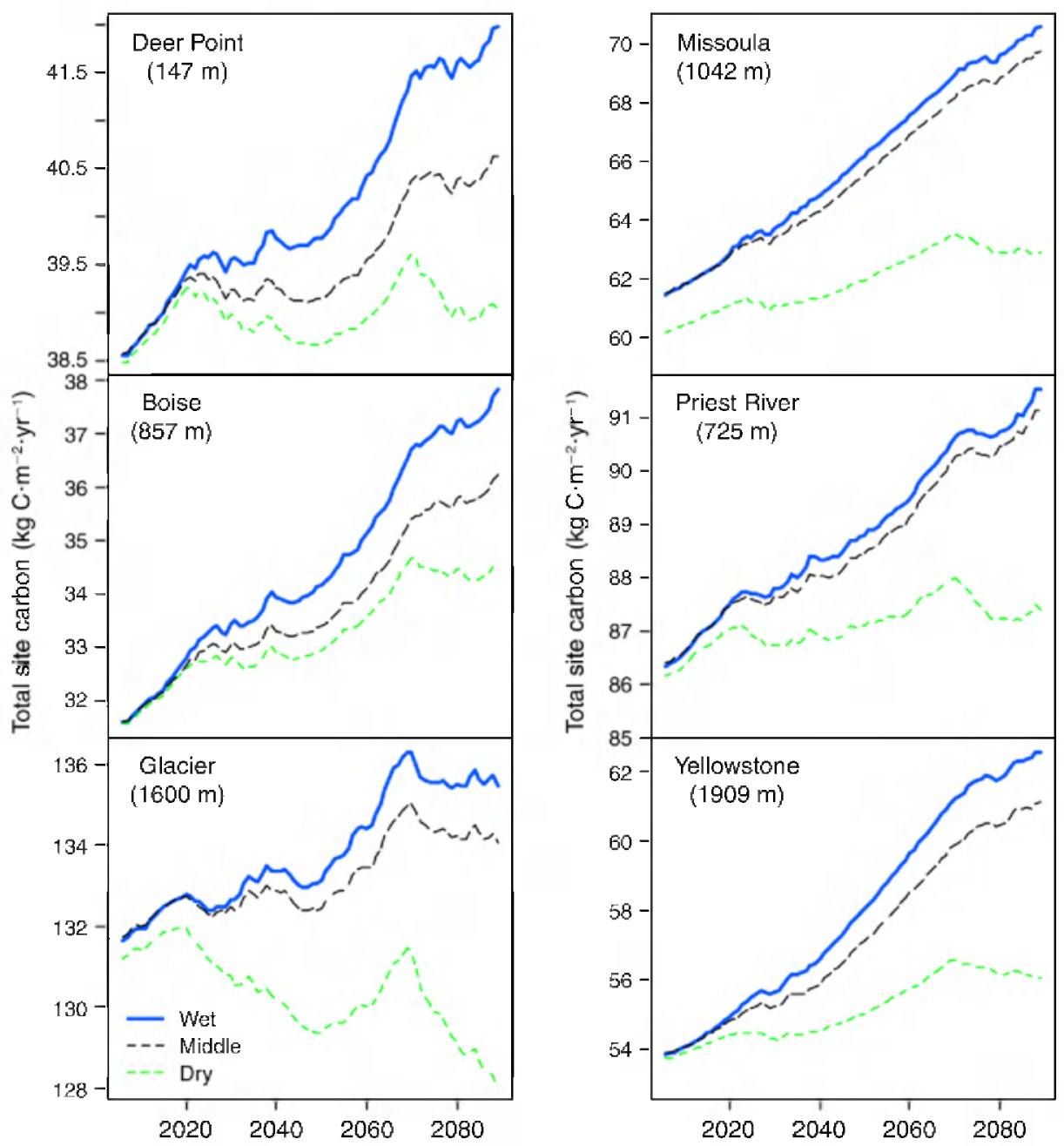

FIG. 9. Total site carbon based on Biome-BGC projections under three climate change scenarios for six sites (elevations in parentheses) across the northern U.S. Rocky Mountains from 2006 to 2089.

insulating snow cover (Monson et al. 2006a, Bergeron et al. 2007).

As per Hu et al.'s (2009) observations, the differences in carbon fluxes and total carbon in our simulations can be explained by changes in growing-season length, snow water, and water stress alone, without accounting for the other changes. The individual effects of other factors, however, cannot be disentangled in our projections, as they are interdependent. Our projections showed limited productivity increases and a 1-3 month increase in water stress days across all sites under the three selected climate change scenarios despite increases in growingseason length, suggesting that in our systems, water drives productivity. In our projections, NPP had a significant negative correlation with water stress days, while respiration had a significant positive correlation with water stress days across all sites for all AOGCMs (Table 5). For Glacier, Missoula, Priest River, and Yellowstone under the wet and middle projections, the correlation between water stress days and NPP is higher
TABLE 5. Correlations between NPP and water stress days and respiration and water stress days for six sites across the northern U.S. Rocky Mountains under three AOGCM projections.

\begin{tabular}{lccc}
\hline \hline & \multicolumn{3}{c}{ AOGCM } \\
\cline { 2 - 4 } Variables and sites & Wet & Middle & Dry \\
\hline NPP & & & \\
Deer Point & -0.45 & -0.54 & -0.62 \\
Boise & -0.42 & -0.44 & -0.53 \\
Glacier & -0.43 & -0.48 & -0.58 \\
Missoula & -0.26 & -0.28 & -0.50 \\
Priest River & -0.18 & -0.21 & -0.39 \\
Yellowstone & -0.19 & -0.18 & -0.34 \\
Respiration & & & \\
Deer Point & 0.37 & 0.27 & 0.27 \\
Boise & 0.38 & 0.39 & 0.36 \\
Glacier & 0.58 & 0.55 & 0.49 \\
Missoula & 0.44 & 0.44 & 0.40 \\
Priest River & 0.55 & 0.56 & 0.56 \\
Yellowstone & 0.40 & 0.46 & 0.50 \\
\hline
\end{tabular}




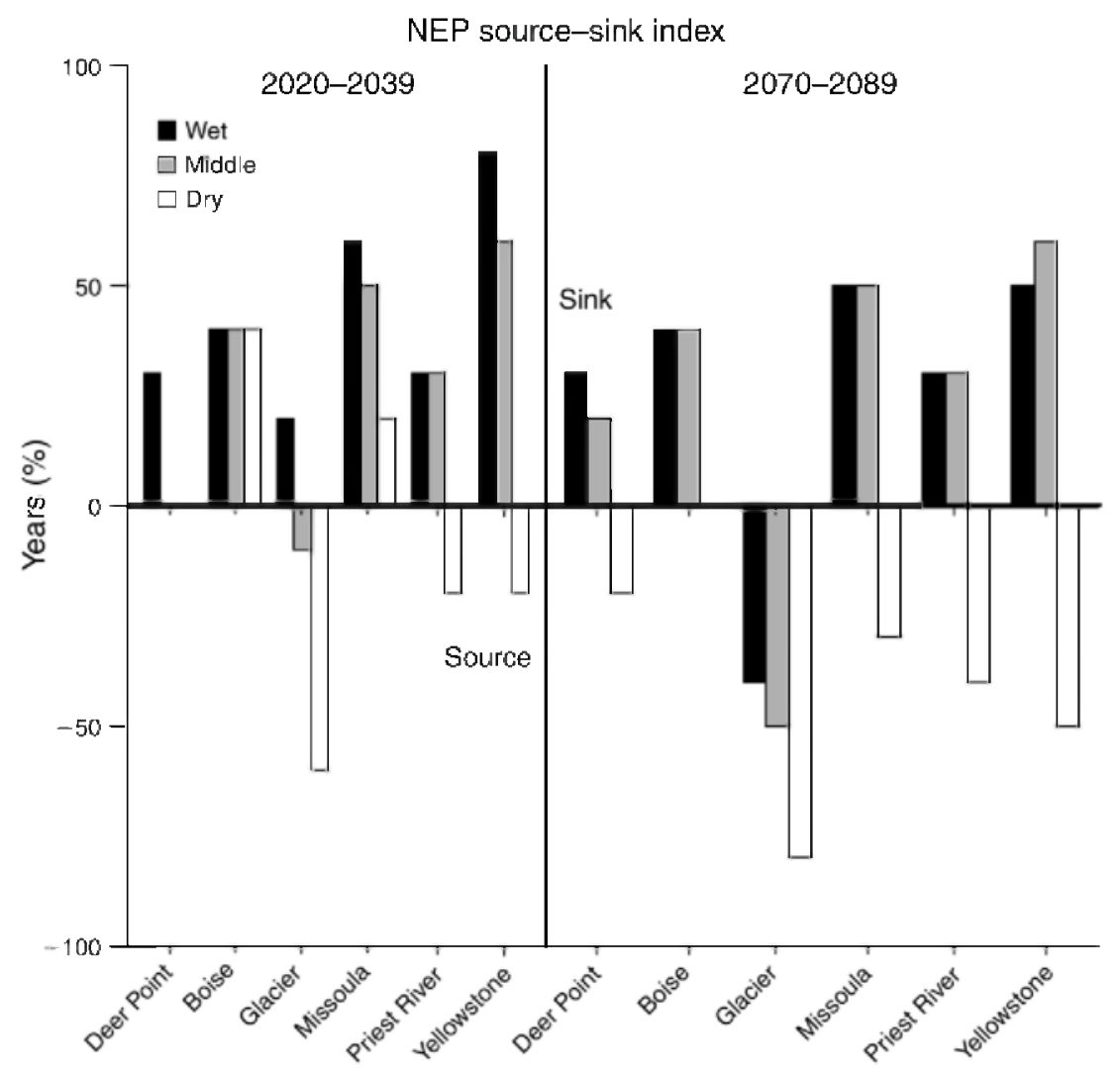

FIG. 10. Carbon source-sink assessment of six sites across the northern U.S. Rocky Mountains during two 20-year periods (2020-2039 and 2070-2089) as projected by Biome-BGC under three climate projections (a wet, middle, and dry AtmosphereOcean General Circulation Model projection). Percentages are the number of years out of 20 that are either carbon sources ( - ) or carbon sinks $(+)$; the 0 line is the cutoff for a site being a carbon source or sink over the whole 20 -year period, for 2020-2039 and $2070-2089$.

(but opposite) than between water stress days and respiration, indicating that a decrease in carbon accumulation may be more attributed to a decrease in gross productivity than with an increase in respiration on these sites. Under the dry projections, only Yellowstone and Priest River maintained that trend. For Missoula and Glacier under the dry projections as well as for Deer Point and Boise under all projections, the decrease in overall carbon seems to be due to a decrease in productivity, a finding similar to Sacks et al. (2007) for Niwot Ridge.

\section{Other factors}

Changes in growing season, water stress, and snow water, driven by the combined temperature and precipitation changes, intermix with the effects of increased $\mathrm{CO}_{2}$ in our simulations. There is published evidence of a $\mathrm{CO}_{2}$ fertilization effect on forests (Moore et al. 2006). Contrary to Mu et al.'s findings (2008), the productivity changes in our simulations are driven more by temperature and water fluctuations than by the fertilization effects of $\mathrm{CO}_{2}$, except for a slight increase in NPP. The $\mathrm{CO}_{2}$ fertilization effect is increasingly qualified; Bergh et al. (2003) identified $\mathrm{CO}_{2}$ effects as species specific; Pan et al. (1998) identified many factors influencing response to elevated $\mathrm{CO}_{2}$, such as VPD levels, $\mathrm{N}$ deposition, and cloud cover, and Bytnerowicz et al. (2007) assert that combined effects of pollution and climate change can change responses to $\mathrm{CO}_{2}$ fertilization. Results from Free Air $\mathrm{CO}_{2}$ Enrichment (FACE) sites around the world present varied responses to $\mathrm{CO}_{2}$ increases, but clearly identify the increasing atmospheric $\mathrm{CO}_{2}$ to be (at the least) a potent restructuring force in vegetation communities (DeLucia et al. 2005, Asshoff et al. 2006). The contrasting responses to elevated $\mathrm{CO}_{2}$ may correspond to the different development stages of forests at respective FACE sites, as disturbance history and stand age also influence forest responses (Ollinger et al. 2002, McIntire et al. 2005, Albani et al. 2006). Thornton et al. (2002) even report Net Ecosystem Exchange (NEE) to be largely a function of disturbance history, with important secondary effects from site climate, vegetation ecophysiology, and changing atmospheric $\mathrm{CO}_{2}$ and $\mathrm{N}$ deposition. A FACE site in Wisconsin found $\mathrm{CO}_{2}$ to increase but $\mathrm{O}_{3}$ to decrease aboveground NPP. Hence, investigators could report no 
detectable response to $\mathrm{CO}_{2}$ and $\mathrm{O}_{3}$ in the high-NPP response to interannual climate variability (Kubiske et al. 2006). High $\mathrm{O}_{3}$ levels damage the photosynthetic apparatus and have been reported to reduce productivity (Ashmore 2005, Cojocariu et al. 2005, Oksanen et al. 2005, Sitch et al. 2007). Our Biome-BGC simulations did not incorporate $\mathrm{O}_{3}$ effects on vegetation, which should not be a factor biasing our results, since $\mathrm{O}_{3}$ levels have not been a reported issue in the northern U.S. Rocky Mountains as defined here. The $\mathrm{CO}_{2}$ fertilization effect is presently represented in Biome-BGC, but it did not compensate for changes in water and temperature levels.

Nitrogen deposition could also change the response of forests to changes in temperature and precipitation (De Vries et al. 2006, Hyvonen et al. 2007). Nanus et al. (2003) mapped N deposition levels across the Rocky Mountains. In the simulation used in this study, wet and dry natural $\mathrm{N}$ depositions were set at $0.004 \mathrm{~kg}$ $\mathrm{N} \cdot \mathrm{m}^{-2} \cdot \mathrm{yr}^{-1}$, with deposition attributed to anthropogenic sources set at $0.0004 \mathrm{~kg} \mathrm{~N} \cdot \mathrm{m}^{-2} \cdot \mathrm{yr}^{-1}$, across all sites. Although these settings are within historical ranges, they do not match those specified by Nanus et al. (2003). The generalized nature of this study, with broad climate projections and no species or age specification, did not seem to warrant the use of precise $\mathrm{N}$ deposition rates, which vary by elevation, slope, aspect, and precipitation amount and by regional and local sources of air pollution. This omission compounds our limited understanding of the physiological response of forests to elevated $\mathrm{CO}_{2}$ and surely contributes to some biases in our projections.

The omission that would most impact our projections is that of large-scale disturbances. The increase in the number of water stress days and the change in snow pack in our simulations would drastically increase the likelihood of disturbances. Water stress levels and snow pack levels are the two main predictors of wildfire vulnerability and factors in insect outbreaks (Fleming et al. 2002, Collins et al. 2006, Raffa et al. 2008), both of which would be favored under our projections. Reduced winter precipitation and an early spring snowmelt already contributed to the recent increase in large wildfire activity (Westerling et al. 2006). The vulnerability of western U.S. forests to more frequent wildfires due to warmer temperatures is reported to be a function of the spatial distribution of forest area and the sensitivity of the local water balance to changes in the timing of spring (Westerling et al. 2006). Our results clearly show the northern U.S. Rocky Mountain forests as being very sensitive to change in the water balance. The impacts of disturbance in carbon stocks and productivity have been demonstrated through reductions of both NPP and NEP (Kang et al. 2006), and determinants in forests being carbon sources or sinks (Kurz et al. 2008a,b). Much like Schumacher and Bugmann's data (2006), our simulations point toward increased fire activity, and the conditions described by
Raffa et al. (2008) warning of increased insect activity under changing climatic conditions, are also supported by our simulations. Although other simulations found that overall positive effects of nondisturbance factors (climate, $\mathrm{CO}_{2}$, and nitrogen) outweighed the effects of increased disturbances in the last two decades (Chen et al. 2003), our results point toward the changes in temperature and precipitation (including the $\mathrm{CO}_{2}$ fertilization effect), which cause deteriorating conditions on forest sites and exacerbate disturbance effects.

The AOGCMs used as our simulation basis have themselves many limitations (Bonan 2008, Running 2008). Processes not yet included in the models, such as the effect of nitrogen on carbon uptake, physiological effects of high ozone concentration, photosynthetic enhancement by diffuse radiation, and disturbance, may initiate unforeseen feedbacks. Forests themselves are a potent modifier to planetary energetics, the hydrologic cycle, and atmospheric composition (Bonan 2008), and vegetation dynamics are barely considered in the current generation of models, nor are fires, aerosols, and reactive chemistry. Our projections incorporate the biases of AOGCMs, and these types of simulations invariably will continue to do so until global circulation models evolve into their next incarnation. The simulation could contribute information to the AOGCMs themselves, as the evaporative effects of climate change on forests are unclear for temperate forests in AOGCMs. The response range in our simulations presents the minimum level of uncertainty in climate projections for this region.

Many other very pertinent factors that we did not consider in our projections would influence the state of forests in the northern U.S. Rocky Mountains. Changes in species composition, stochastic changes in patterns of environmental factors, such as precipitation, may have potentially stronger effects on ecological systems than do changes in average conditions that we represented here (White et al. 1998, Weltzin et al. 2003, Hamann and Wang 2006, Jump et al. 2006, Sefcik et al. 2007). Recently reported increases in drought-induced mortality (van Mantgem et al. 2009) would also change the landscape and forest dynamics; e.g., sites similar to Boise, on the edge of the grassland-forests ecotone, are already hovering close to nonforested precipitation levels (average between 2006 and 2089 of $30 \mathrm{~cm} / \mathrm{yr}$ ). Time since disturbance influences carbon exchanges on sites (Law et al. 2001, Magnani et al. 2007), as do management regimes (Briceno-Elizondo et al. 2006, De Vries et al. 2006) and stand age (Chen et al. 2002, Yarie and Parton 2005). Despite these omissions, our simulations did lead to a more in-depth exploration of the effects of temperature and precipitation scenarios on forests in the northern U.S. Rocky Mountains.

\section{ACKNOWLEDGMENTS}

This research was supported by a grant from the William and Flora Hewlett Foundation and coordinated through Joel Smith from Stratus Consulting, Washington, D.C., USA. 


\section{Literature Cited}

Albani, M., D. Medvigy, G. C. Hurtt, and P. R. Moorcroft. 2006. The contributions of land-use change, $\mathrm{CO}_{2}$ fertilization, and climate variability to the Eastern US carbon sink. Global Change Biology 12:2370-2390.

Anthoni, P. M., B. E. Law, and M. H. Unsworth. 1999. Carbon and water vapor exchange of an open-canopied ponderosa pine ecosystem. Agricultural and Forest Meteorology 95: $151-168$.

Ashmore, M. R. 2005. Assessing the future global impacts of ozone on vegetation. Plant, Cell and Environment 28:949964.

Asshoff, R., G. Zotz, and C. Körner. 2006. Growth and phenology of mature temperate forest trees in elevated $\mathrm{CO}_{2}$. Global Change Biology 12:848-861.

Bachelet, D., R. P. Neilson, J. M. Lenihan, and R. J. Drapek. 2004. Regional differences in the carbon source-sink potential of natural vegetation in the U.S.A. Environmental Management 33:S23-S43.

Barr, A. G., T. A. Black, E. H. Hogg, T. J. Griffis, K. Morgenstern, N. Kljun, A. Theede, and Z. Nesic. 2007. Climatic controls on the carbon and water balances of a boreal aspen forest, 1994-2003. Global Change Biology 13: $561-576$.

Bergeron, O., H. A. Margolis, T. A. Black, C. Coursolle, A. L. Dunn, A. G. Barr, and S. C. Wofsy. 2007. Comparison of carbon dioxide fluxes over three boreal black spruce forests in Canada. Global Change Biology 13:89-107.

Bergh, J., M. Freeman, B. Sigurdsson, S. Kellomäki, K. Laitinen, S. Niinistö, H. Peltola, and S. Linder. 2003. Modelling the short-term effects of climate change on the productivity of selected tree species in Nordic countries. Forest Ecology and Management 183:327-340.

Boisvenue, C., and S. W. Running. 2006. Impacts of climate change on natural forest productivity-evidence since the middle of the 20th century. Global Change Biology 12:862 882.

Bonan, G. B. 2008. Forests and climate change: forcings, feedbacks, and the climate benefits of forests. Science 320: $1444-1449$.

Bond-Lamberty, B., S. T. Gower, D. E. Ahl, and P. E. Thornton. 2005. Reimplementation of the Biome-BGC model to simulate successional change. Tree Physiology 25: 413-424.

Briceno-Elizondo, E., J. Garcia-Gonzalo, H. Peltola, and S. Kellomäki. 2006. Carbon stocks and timber yield in two boreal forest ecosystems under current and changing climatic conditions subjected to varying management regimes. Environmental Science and Policy 9:237-252.

Bytnerowicz, A., K. Omasa, and E. Paoletti. 2007. Integrated effects of air pollution and climate change on forests: a northern hemisphere perspective. Environmental Pollution 147:438-445.

Carter, G. A., W. K. Smith, and J. L. Hadley. 1988. Stomatal conductance in three conifer species at different elevations during summer in Wyoming. Canadian Journal of Forest Research 18:242-246.

Chapin, F. S., III, et al. 2006. Reconciling carbon-cycle concepts, terminology, and methods. Ecosystems 9:10411050.

Chen, J. M., W. Ju, J. Cihlar, D. Price, J. Liu, W. J. Chen, J. Pan, A. Black, and A. Barr. 2003. Spatial distribution of carbon sources and sinks in Canada's forests. Tellus 55B: $622-641$.

Chen, W., J. M. Chen, D. T. Price, and J. Cihlar. 2002. Effects of stand age on net primary productivity of boreal black spruce forests in Ontario, Canada. Canadian Journal of Forest Research 32:833-842.

Christensen, J. H., et al. 2007. Regional climate projections. Pages 847-940 in S. Solomon, D. Qin, M. Manning, Z. Chen,
M. Marquis, K. B. Averyt, M. Tignor, and H. L. Miller, editors. Contribution of Working Group I to the Fourth Assessment Report of the Intergovernmental Panel on Climate Change. Cambridge University Press, Cambridge, UK.

Churkina, G., and S. W. Running. 1998. Contrasting climatic controls on the estimated productivity of global terrestrial biomes. Ecosystems 1:206-215.

Churkina, G., J. Tenhunen, P. Thornton, E. M. Falge, J. A. Elbers, M. Erhard, T. Grünwald, A. S. Kowalski, Ü. Rannik, and D. Sprinz. 2003. Analyzing the ecosystem carbon dynamics of four European coniferous forests using a biogeochemistry model. Ecosystems 6:168-184

Cojocariu, C., P. Escher, K.-H. Häberle, R. Matyssek, H. Rennenberg, and J. Kreuzwieser. 2005. The effect of ozone on the emission of carbonyls from leaves of adult Fagus sylvatica. Plant, Cell and Environment 28:603-611.

Collins, B. M., P. N. Omi, and P. L. Chapman. 2006. Regional relationships between climate and wildfire-burned area in the Interior West, USA. Canadian Journal of Forest Research 36:699-709.

Dang, H., M. Jiang, Q. Zhang, and Y. Zhang. 2007. Growth responses of subalpine fir (Abies fargesii) to climate variability in the Qinling Mountain, China. Forest Ecology and Management 240:143-150.

DeLucia, E. H., D. J. Moore, and R. J. Norby. 2005. Contrasting responses of forest ecosystems to rising atmospheric $\mathrm{CO}_{2}$ : implications for the global $\mathrm{C}$ cycle. Global Biogeochemical Cycles 19:GB3006.

De Vries, W., G. J. Reinds, P. Gundersen, and H. Sterba. 2006. The impact of nitrogen deposition on carbon sequestration in European forests and forest soils. Global Change Biology 12: $1151-1173$.

Fleming, R. A., J.-N. Condou, and R. S. McAlpine. 2002. Landscape-scale analysis of interactions between insect defoliation and forest fire in Central Canada. Climatic Change 55:251-272.

Hamann, A., and T. Wang. 2006. Potential effects of climate change on ecosystem and tree species distribution in British Columbia. Ecology 87:2773-2786.

Hopkins, W. G., and N. P. A. Hüner. 2004. Introduction to plant physiology. Third edition. John Wiley and Sons, Hoboken, New Jersey, USA.

Hu, J., D. J. P. Moore, S. P. Burns, and R. K. Monson. 2009. Longer growing seasons lead to less carbon sequestration by a subalpine forest. Global Change Biology 16:771-783.

Hyvönen, R., et al. 2007. The likely impact of elevated $\left[\mathrm{CO}_{2}\right]$, nitrogen deposition, increased temperature and management on carbon sequestration in temperate and boreal forest ecosystems: a literature review. New Phytologist 173:463-480.

IPCC. 2003. IPCC meeting on current scientific understanding of the processes affecting terrestrial carbon stocks and human influences upon them. Intergovernmental Panel on Climate Change (IPCC) Working Group I Technical Support UnitNational Oceanic and Atmospheric Administration (NOAA), Geneva, Switzerland.

IPCC. 2007. Climate change 2007: the physical science basis. In S. Solomon, D. Qin, M. Manning, Z. Chen, M. Marquis, K. B. Averyt, M. Tignor, and H. L. Miller, editors. Contribution of Working Group I to the Fourth Assessment Report of the Intergovernmental Panel on Climate Change. Cambridge University Press, Cambridge, UK.

Jansen, E., et a1. 2007. Palaeoclimate. Pages 433-497 in S. Solomon, D. Qin, M. Manning, Z. Chen, M. Marquis, K. B. Averyt, M. Tignor, and H. L. Miller, editors. Contribution of Working Group I to the Fourth Assessment Report of the Intergovernmental Panel on Climate Change. Cambridge University Press, Cambridge, UK.

Jolly, W. M., R. Nemani, and S. W. Running. 2005. A generalized, bioclimatic index to predict foliar phenology in response to climate. Global Change Biology 11:619-632. 
Jones, P. D., and M. E. Mann. 2004. Climate over the past millenia. Reviews of Geophysics 42:RG2002.

Jump, A. S., J. M. Hunt, and J. Peñuelas. 2006. Rapid climate change-related growth decline at the southern range edge of Fagus sylvatica. Global Change Biology 12:2163-2174.

Kang, S., J. S. Kimball, and S. W. Running. 2006. Simulating effects of fire disturbance and climate change on boreal forest productivity and evapotranspiration. Science of the Total Environment 362:85-102.

Kirschbaum, M. U. F. 2004. Assessing long-term trend in forest productivity under changing climatic conditions. Presentation. IUFRO 4.01.09 Process Based Models for Forest Management - International Conference on Modeling Forest Production. Department of Ecology, University of Natural Resources and Applied Life Sciences, Vienna, Austria.

Knapp, A. K., and M. D. Smith. 2001. Variation among biomes in temporal dynamics of aboveground primary production. Science 291:481-484.

Knowles, N., M. D. Dettinger, and D. R. Cayan. 2005. Trends in snowfall versus rainfall for the western United States. Journal of Climate 19:4545-4559.

Körner, C., R. Asshoff, O. Bignucolo, S. Hăttenschwiler, S. G. Keel, S. Peláez-Riedl, S. Pepin, R. T. W. Siegwolf, and G. Zotz. 2005. Carbon flux and growth in mature deciduous forest trees exposed to elevated $\mathrm{CO}_{2}$. Science 309:1360-1362.

Kubiske, M. E., V. S. Quinn, W. E. Heilman, E. P. McDonald, P. E. Marquardt, R. M. Teclaw, A. L. Friend, and D. F. Karnosky. 2006. Interannual climatic variation mediates elevated $\mathrm{CO}_{2}$ and $\mathrm{O}_{3}$ effects on forest growth. Global Change Biology 12:1054-1068.

Kurz, W. A., C. C. Dymond, G. Stinson, G. J. Rampley, E. T. Neilson, A. L. Carroll, T. Ebata, and L. Safranyik. 2008 a. Mountain pine beetle and forest carbon feedback to climate change. Nature 452:987-990.

Kurz, W. A., G. Stinson, G. J. Rampley, C. C. Dymond, and E. T. Neilson. 2008b. Risk of natural disturbances makes future contribution of Canada's forests to the global carbon cycle highly uncertain. Proceedings of the National Academy of Sciences USA 105:1551-1555.

Law, B. E., P. E. Thornton, J. Irvine, P. M. Anthoni, and S. Van Tuyl. 2001. Carbon storage and fluxes in ponderosa pine forests at different developmental stages. Global Change Biology 7:755-777

Magnani, F., et al. 2007. The human footprint in the carbon cycle of temperate and boreal forests. Nature 447:848-850.

McIntire, E. J. B., R. Duchesneau, and J. P. Kimmins. 2005. Seed and bud legacies interact with varying fire regimes to drive long-term dynamics of boreal forest communities. Canadian Journal of Forest Research 35:2765-2773.

Menzel, A., et al. 2006. European phenological response to climate change matches the warming pattern. Global Change Biology 12:1969-1976.

Monson, R. K., S. P. Burns, M. W. Williams, A. C. Delany, M. Weintraub, and D. A. Lipson. 2006a. The contribution of beneath-snow soil respiration to total ecosystem respiration in a high-elevation, subalpine forest. Global Biochemical Cycles 20:GB3030.

Monson, R. K., D. L. Lipson, S. P. Burns, A. A. Turnipseed, A. C. Delany, M. W. Williams, and S. K. Schmidt. $2006 b$. Winter forest soil respiration controlled by climate and microbial community composition. Nature 439:711-714.

Monson, R. K., A. A. Turnipseed, J. P. Sparks, P. C. Harley, L. E. Scott-Denton, K. Sparks, and T. E. Huxman. 2002. Carbon sequestration in a high-elevation, subalpine forest. Global Change Biology 8:459-478.

Moore, D. J. P., S. Aref, R. M. Ho, J. S. Pippen, J. G. Hamilton, and E. H. De Lucia. 2006. Annual basal area increment and growth duration of Pinus taeda in response to eight years of free-air carbon dioxide enrichment. Global Change Biology 12:1367-1377.
Morales, P., T. Hickler, D. P. Rowell, B. Smith, and M. T. Sykes. 2007. Changes in European ecosystem productivity and carbon balance driven by regional climate model output. Global Change Biology 13:108-122.

Mu, Q., M. Zhao, S. W. Running, M. Liu, and H. Tian. 2008. Contribution of increasing $\mathrm{CO}_{2}$ and climate change to the carbon cycle in China's ecosystems. Journal of Geophysical Research 113:G01018.

Nakicenovic, N., et al. 2000. IPCC Special Report on Emissions Scenarios. Cambridge University Press, New York, New York, USA.

Nanus, L., D. H. Campbell, G. P. Ingersoll, D. W. Clow, and M. A. Mast. 2003. Atmospheric deposition maps for the Rocky Mountains. Atmospheric Environment 37:4881-4892.

Nemani, R. R., C. D. Keeling, H. Hashimoto, W. M. Jolly, S. C. Piper, C. J. Tucker, R. B. Myneni, and S. W. Running. 2003. Climate-driven increases in global terrestrial net primary production from 1982 to 1999 . Science $300: 1560$ 1563.

Oksanen, E., V. Freiwald, N. Prozherina, and M. Rousi. 2005. Photosynthesis of birch (Betula pendula) is sensitive to springtime frost and ozone. Canadian Journal of Forest Research 35:703-712.

Ollinger, S. V., J. D. Aber, P. B. Reich, and R. J. Freuder. 2002. Interactive effects of nitrogen deposition, tropospheric ozone, elevated $\mathrm{CO}_{2}$ and land use history on the carbon dynamics of northern hardwood forests. Global Change Biology 8:545562 .

Oren, R., B. E. Ewers, P. Todd, N. Phillips, and G. Katul. 1998. Water balance delineates the soil layer in which moisture affects canopy conductance. Ecological Applications 8:9901002.

Pan, Y., et a1. 1998. Modeled responses of terrestrial ecosystems to elevated atmospheric $\mathrm{CO}_{2}$ : a comparison of simulations by the biogeochemistry models of the Vegetation/Ecosystem Modeling and Analysis Project (VEMAP). Oecologia 114: 389-404.

Piao, S., et al. 2008. Net carbon dioxide losses of northern ecosystems in response to autumn warming. Nature $451: 49$ 52.

Qian, T., A. Dai, K. E. Trenberth, and K. Oleson. 2006. Simulation of global land surface conditions from 1948 to 2004. Part I: Forcing data and evaluations. Journal of Hydrometeorology 7:953-975.

Raffa, K. F., B. H. Aukema, B. J. Bentz, A. L. Carroll, J. A. Hicke, M. G. Turner, and W. H. Romme. 2008. Cross-scale drivers of natural disturbances prone to anthropogenic amplification: the dynamics of bark beetle eruptions. BioScience 58:501-517.

Randall, D. A., et al. 2007. Climate models and their evaluation. Pages 589-662 in S. Solomon, D. Qin, M. Manning, Z. Chen, M. Marquis, K. B. Averyt, M. Tignor, and H. L. Miller, editors. Contribution of Working Group I to the Fourth Assessment Report of the Intergovernmental Panel on Climate Change. Cambridge University Press, Cambridge, UK.

Reichstein, M., et al. 2007. Reduction of ecosystem productivity and respiration during the European summer 2003 climate anomaly: a joint flux tower, remote sensing and modelling analysis. Global Change Biology 13:634-651.

Rodriguez-Iturbe, I. 2000. Ecohydrology: a hydrologic perspective of climate-soil-vegetation dynamics. Water Resources Research 36:3-9.

Running, S. W. 2008. Climate change: ecosystem disturbance, carbon, and climate. Science 321:652-653.

Running, S. W., and S. T. Gower. 1991. FOREST-BGC, a general model of forest ecosystem processes for regional applications. II. Dynamic carbon allocation and nitrogen budgets. Tree Physiology 9:147-160.

Running, S. W., and E. R. Hunt, Jr. 1993. Generalization of a forest ecosystem process model for other biomes, BIOME- 
BGC, and an application for global-scale models. Pages 141 158 in J. R. Ehleringer and C. Field, editors. Scaling physiological processes: leaf to globe. Academic Press, San Diego, California, USA.

Running, S. W., R. R. Nemani, F. A. Heinsch, M. Zhao, M. Reeves, and H. Hashimoto. 2004. A continuous satellitederived measure of global terrestrial primary production. BioScience 54:547-560.

Sacks, W. J., D. S. Schimel, and R. K. Monson. 2007. Coupling between carbon cycling and climate in a high-elevation, subalpine forest: a model-data fusion analysis. Oecologia 151:54-68.

Schimel, D., T. G. F. Kittel, S. Running, R. Monson, A. Turnipseed, and D. Anderson. 2002. Carbon sequestration studied in western U.S. mountains. EOS, Transactions of the American Geophysical Union 83:445.

Schumacher, S., and H. Bugmann. 2006. The relative importance of climatic effects, wildfires and management for future forest landscape dynamics in the Swiss Alps. Global Change Biology 12:1435-1450.

Sefcik, L. T., D. R. Zak, and D. S. Ellsworth. 2007. Seedling survival in a northern temperate forest understory is increased by elevated atmospheric carbon dioxide and atmospheric nitrogen deposition. Global Change Biology 13:132-146.

Service, R. F. 2004. Water resources: as the West goes dry. Science 303:1124-1127.

Sheffield, J., G. Goteti, F. Wen, and E. F. Wood. 2004. A simulated soil moisture based drought analysis for the United States. Journal of Geophysical Research 109:D24108.

Sitch, S., P. M. Cox, W. J. Collins, and C. Huntingford. 2007. Indirect radiative forcing of climate change through ozone effects on the land-carbon sink. Nature 448:791-794.

Tebaldi, C., R. L. Smith, D. Nychka, and L. O. Mearns. 2005. Quantifying uncertainty in projections of regional climate change: A Bayesian approach to the analysis of multimodel ensembles. Journal of Climate 18:1524-1540.

Thornton, P. E. 1998a. Regional ecosystem simulation: combining surface and satellite-based observations to study linkages between terrestrial energy and mass budgets. Thesis (partial). University of Montana, Missoula, Montana, USA.

Thornton, P. E. 1998b. Description of a numerical simulation model for predicting the dynamics of energy, water, carbon and nitrogen in a terrestrial ecosystem. Thesis (partial). University of Montana, Missoula, Montana, USA.

Thornton, P. E., B. E. Law, H. L. Gholz, K. L. Clark, E. Falge, D. S. Ellsworth, A. H. Goldstein, R. K. Monson, D. Hollinger, M. Falk, J. Chen, and J. P. Sparks. 2002. Modeling and measuring the effects of disturbance history and climate on carbon and water budgets in evergreen needleleaf forests. Agricultural and Forest Meteorology 113: $185-222$.

Thornton, P. E., and S. W. Running. 1999. An improved algorithm for estimating incident daily solar radiation from measurements of temperature, humidity, and precipitation. Agricultural and Forest Meteorology 93:211-228.

Thornton, P. E., S. W. Running, and M. A. White. 1997. Generating surfaces of daily meteorological variables over large regions of complex terrain. Journal of Hydrology 190: 214-251.

van Mantgem, P. J., N. L. Stephenson, J. C. Byrne, L. D. Daniels, J. F. Franklin, P. Z. Fulé, M. E. Harmon, A. J. Larson, J. M. Smith, A. H. Taylor, and T. T. Veblen. 2009. Widespread increase of tree mortality rates in the Western United States. Science 323:521-524.

Vetter, M., et al. 2005. Partitioning direct and indirect humaninduced effects on carbon sequestration of managed coniferous forests using model simulations and forest inventories. Global Change Biology 11:810-827.

Waring, R. H., and S. W. Running. 2007. Forest ecosystems: analysis at multiple scales. Third edition. Academic Press, San Diego, California, USA.

Weltzin, J. F., et al. 2003. Assessing the response of terrestrial ecosystems to potential changes in precipitation. BioScience 53:941-952.

Westerling, A. L., H. G. Hidalgo, D. R. Cayan, and T. W. Swetnam. 2006. Warming and earlier spring increase western U.S. forest wildfire activity. Science 313:940-943.

White, J. D., S. W. Running, P. E. Thornton, R. E. Keane, K. C. Ryan, D. B. Fagre, and C. H. Key. 1998. Assessing simulated ecosystem processes for climate variability research at Glacier National Park, USA. Ecological Applications 8: 805-823.

White, J. D., N. A. Scott, A. I. Hirsch, and S. W. Running. 2006. 3-PG productivity modeling of regenerating Amazon forests: climate sensitivity and comparison with MODISderived NPP. Earth Interactions 10:1-26.

White, M. A., P. E. Thornton, S. W. Running, and R. R. Nemani. 2000. Parameterization and sensitivity analysis of the BIOME-BGC terrestrial ecosystem model: net primary production controls. Earth Interactions 4:1-85.

Yarie, J., and B. Parton. 2005. Potential changes in carbon dynamics due to climate change measured in the past two decades. Canadian Journal of Forest Research 35:2258-2267.

Zhao, M., and G.-S. Zhou. 2006. Carbon storage of forest vegetation in China and its relationship with climatic factors. Climatic Change 74:175-189. 